\title{
MIĘDZY LĘKIEM A SZTUKĄ. KOBIETA W TWÓRCZOŚCI HALINY KORN-ŻULAWSKIEJ
}

\author{
Katarzyna MOSKAŁA (Toruń)
}

Halina Korn Żuławska to - w ,polskim Londynie” — jedna z wielu malarek „nieprofesjonalnych”, których twórczość nie została jeszcze zbadana, sklasyfikowana i poddana krytyce ${ }^{1}$. Niemniej jednak cały bogaty dorobek artystyczny H. Korn, zarówno malarski jak i rzeźbiarski, zasługuje na uwagę i rzetelne opracowanie naukowe nie tylko ze względu na barwność i złożoność jej osobowości, ale głównie z powodu sztuki, jaką tworzyła. O niewątpliwej wartości i jakości jej dorobku artystycznego może świadczyć znaczna liczba ekspozycji w uznanych galeriach sztuki zarówno w Europie, jak i Stanach Zjednoczonych; w wystawach tych artystka brała udział od 1942 roku $^{2}$.

Najpełniejszym źródłem informacji o sztuce Haliny Korn są artykuły prasowe, wspomnienia i relacje przyjaciół oraz współczesnych jej uczestników polskiego życia artystycznego w Wielkiej Brytanii: Alicji Drwęskiej, Marka Żuławskiego i Feliksa Topolskiego. Informacje i zapiski o dorobku artystycznym oraz niezwykle bogatą korespondencję Haliny Korn i Marka Żuławskiego gromadziła trzecia żona malarza Maria, która przekazała je do zbiorów toruńskiego Archiwum Emigracji, przyczyniając się tym samym do upowszechnienia nieznanych dotąd informacji oraz powstania nowych publikacji i opracowań ${ }^{3}$.

Niezmiernie ważnym faktem, a zarazem ułatwieniem dla badaczy twórczości Korn, był dar dla Torunia od Marii Żuławskiej w postaci części jej prywatnych zbiorów: w Muzeum Uniwersyteckim UMK znaleźć można kolekcję obrazów i rysunków.

\footnotetext{
${ }^{1}$ Autorka przygotowuje obszerniejszą pracę na temat malarek polskich w Wielkiej Brytanii w XX wieku.

${ }^{2}$ Wystawa Kobiety Polskiej, Dziennik Polski 1942 nr 558, s. 4. Pełną listę wystaw H. Korn zawiera: M. A. Supruniuk, Polskie życie artystyczne $w$ Wielkiej Brytanii $w X X w$. (praca w przygotowaniu; udostępniona dzięki życzliwości autora).

${ }^{3}$ Przykładem takiego upowszechnienia jest ilustrowany biogram malarki na portalu „,Sztuka polska na świecie”, opracowany przez Joannę Krasnodębską: http://www.muzeum.umk.pl/sztuka_polska/halina-korn (dostęp: maj 2016).
} 
Kilkadziesiąt obrazów i rysunków artystki zakupiło też Muzeum Narodowe w Warszawie, zaś reszta jej prac znajduje się w wielu galeriach i prywatnych kolekcjach na świecie.

Analizując stan badań dorobku artystycznego H. Korn, można stwierdzić, że liczba publikacji na jej temat stale wzrastała. Na początku były to niewielkie wzmianki o twórczości czy też wymienienie nazwiska wraz z grupą innych artystów, do której przez danego piszącego była kwalifikowana, bądź z którymi wystawiała swoje obrazy w londyńskich galeriach sztuki. Z czasem publikacje stawały się coraz obszerniejsze i podawały więcej informacji na temat sztuki Korn. Zdecydowana większość artykułów to te autorstwa Alicji Drwęskiej, malarki, recenzentki i krytyka sztuki, popularyzującej sztukę polskich artystów, tworzących w Wielkiej Brytanii, w głównych czasopismach emigracyjnych ${ }^{4}$. Jej artykuły, w których pisała o Halinie Korn, ukazywały się m.in. w „Dzienniku Polskim i Dzienniku Żołnierza”, „Orle Białym”, „Wiadomościach” i „Tygodniu Polskim”, w latach: 1950-1977 . Na uwagę zasługują teksty o sztuce Korn, pisane przez angielskich publicystów, jak choćby artykuły w „Studio” z 1956 roku $^{6}$, "The Scotsman"7 z 1964 roku czy uwzględnienie artystki w anglojęzycznym wydaniu słownika artystów, działających w Anglii po 1945 roku — The Dictionary of Artists In Britain Since $1945^{8}$ autorstwa Davida Buckmana oraz Face to Face. British Self-Portraits in the Twentieth Century ${ }^{9}$ Philipa Vanna - co prawda publikacja ta nie wnosi nic nowego do wiedzy o sztuce Korn, ale pozwala przypuszczać, że twórczość polskiej artystki została w Londynie dostrzeżona i doceniona, skoro umieszczono jej nazwisko wśród znanych i cenionych artystów, takich jak: Oskar Kokoscha, Henry Moore czy Francis Bacon.

Duże znaczenie dla stanu badań nad sztuką Korn mają artykuły Zygmunta Turkiewicza z cyklu Wystawy londyńskie ${ }^{10}$ w paryskiej „Kulturze” oraz ilustrowany szkic wspomnieniowy Marka Żuławskiego i Feliksa Topolskiego Halinka ${ }^{11}$, opublikowany w „Wiadomościach”. Nieoceniona wydaje się autobiografia męża artystki — Marka Żuławskiego, obcującego z malarką na co dzień, uczącego ją i dzielącego z nią pracownię. Jego trzyczęściowe Studium do autoportretu ${ }^{12}$ zawiera wiele cennych informacji o osobowości Korn — o tym, jaka była prywatnie, a także o jej sytuacji życiowej $\mathrm{i}$ artystycznej.

\footnotetext{
${ }^{4}$ Por.: Sztuka polska w Wielkiej Brytanii 1940-2000: antologia, oprac. M. A. Supruniuk, Toruń 2006.

${ }^{5}$ A. Drwęska, Po londyńskim sezonie wystaw, Orzeł Biały 1950 nr 41, s. 5; taż, Pótroczny bilans malarski, Orzeł Biały $1951 \mathrm{nr} 38$, s. 3; taż, O prymitywach $i$ wystawie Haliny Korn, Wiadomości $1953 \mathrm{nr} 44$ (396), s. 3; taż, Wystawa międzynarodowa kobiet-malarek, Dziennik Polski i Dziennik Żołnierza 1955, s. 3; taż, Akty i fakty, Tydzień Polski 1974 nr 22, s. 5; taż, Wystawy zimowego kwartalu, Tydzień Polski 1977 nr 16, s. 7.

${ }^{6}$ M. Goff, Marek Zulawski and Halina Korn, Studio 1956 wol. 152, s. 108-111.

${ }^{7}$ S. Goodsir, A „Primitive” at the Traverse, The Scotsman 25.09.1964, s. 13.

8 D. Buckman, The Dictionary of Artists in Britain since 1945, Bristol 1998; 2 wyd. poszerzone 2006 .

${ }^{9}$ P. Vann, Face to Face. British Self-Portraits in the Twientieth Century, London 2004.

${ }^{10}$ Z. Turkiewicz, Wystawy londyńskie, Kultura 1966 nr 1-2 (219-220), s. 199-202.

${ }^{11}$ F. Topolski, M. Żuławski, Halinka, Wiadomości $1979 \mathrm{nr} 3$ (1712), s. 5.

12 M. Żuławski, Studium do autoportretu, Toruń 2009. Wydanie zawiera dwie wydane wcześniej części (Warszawa 1980, 1990), uzupełnione niepublikowanym fragmentem, obejmującym okres ostatnich lat życia artysty.
} 
W rozwoju badań nad sztuką artystki nie można pominąć publikacji Aleksandra Jackowskiego, Sztuka zwana naiwna. Zarys encyklopedyczny twórczości w Polsce ${ }^{13}$, którą można uznać za jedną z istotniejszych; po pierwsze była to pionierska próba sklasyfikowania twórczości Korn na gruncie polskim, po drugie jej autor, z wykształcenia historyk sztuki i etnograf, jest wybitnym znawcą sztuki naiwnej i prymitywnej, co przełożyło się na fachowość i rzeczowość analizy sztuki Korn. Wykorzystano także artykuł Sztuka oswajania świata. O obecnościach twórczości plastycznej niepetnosprawnych umystowo w polskiej sztuce wspótczesnej Jana Wiktora Sienkiewicza ${ }^{14}$.

W 2006 roku ukazała się publikacja cenna nie tylko ze względu na to, iż zawiera wiele informacji o Halinie Korn, ale i dlatego, że pokazuje szerokie spektrum sztuki, tworzonej przez polskich artystów na emigracji: Sztuka polska w Wielkiej Brytanii 1940-2000. Antologia w opracowaniu i ze wstępem Mirosława A. Supruniuka (Toruń 2006), który zebrał artykuły, ukazujące się w polskojęzycznej prasie emigracyjnej.

Twórczość Haliny Korn jest niezwykle różnorodna: artystka, oprócz malarstwa, zajmowała się rzeźbą i krytyką sztuki, ponadto jest autorką książki Wakacje kończa się we wrześniu ${ }^{15}$, stanowiącą rodzaj pamiętnika lat dziecięcych, spisanego i zilustrowanego przez dojrzałą artystkę.

Jednym z głównych wątków w rozważaniach nad twórczością Korn jest ten dotyczący „naiwności” jej sztuki czy też braku wykształcenia akademickiego. W tych rozważaniach uwzględnić należy fakt, że twórczość polskiej artystki kształtowała się w oparciu o profesjonalne rady jej męża-malarza, który w jednym z listów do niej napisał:

[...] masz rację, że nie chcesz oglądać rzeczy, które Cię niczego nie uczą — kieruj się swoim niezawodnym instynktem, ale staraj się zrozumieć dlaczego instynkt Cię do tego a nie czego innego skłania. W ten sposób zdobywa się w sztuce wiedzę i buduje swoją świadomość artystyczną ${ }^{16}$.

Powtórzył to później w autobiografii ${ }^{17}$. Zygmunt Turkiewicz w recenzji wystawy, w której artystka brała udział, napisał:

Sztuka Haliny Korn należy do tych rzadkich zdarzeń, które powstają w specyficznych warunkach. W tym wypadku brak formalnych studiów plastycznych malarki wychodzi jej na dobre. Trzymanie pędzli w czystości i unikanie naśladowań innych malarzy, oto dwie rady, których usłuchała ${ }^{18}$.

W jednym z wielu listów, napisanych do Marka, H. Korn podkreśla swoją wdzięczność za wszelkie artystyczne i techniczne wskazówki:

[...] nie ma nikogo co by mi powiedział w którym miejscu komuś nogi rosną z tyłka ani

${ }^{13}$ A. Jackowski, Sztuka zwana naiwną. Zarys encyklopedyczny twórczości w Polsce, Warszawa 1995, s. 86.

${ }^{14}$ J. W. Sienkiewicz, Sztuka oswajania świata. O obecnościach twórczości plastycznej niepetnosprawnych umystowo $w$ polskiej sztuce wspótczesnej, [w:] Osoby niepetnosprawne w życiu społeczeństwa i kościoła, red. A. Bartoszek, D. Sitko, t. 1, Katowice-Ruda Śląska 2003, s. 123-151.

${ }^{15}$ H. Korn-Żuławska, Wakacje kończa się we wrześniu, Warszawa 1983.

${ }^{16}$ Archiwum Emigracji w Toruniu, Archiwum Haliny Korn-Żuławskiej (dalej: AE/HK-Ż), list M. Żuławskiego do H. Korn, lipiec [?] 1949.

${ }^{17}$ M. Żuławski, Studium do autoportretu, s. 161-162.

${ }^{18}$ Z. Turkiewicz, Wystawy londyńskie, s. 199-202. 
jak posadzić faceta żeby mi nie spadł z ławki, a ja bez Twoich wskazówek tak się strasznie zniechęcam do całej swojej tak zwanej „,sztuki”. Pewnie, że jestem zdolna jak cholera [...] ale nie umiem no nie umiem dawać sobie rady w życiu bez Ciebie ${ }^{19}$.

Niezwykle barwnie i wyczerpująco o twórczości Haliny Korn napisała Helena Heinsdorf:

Najznamienitszą chyba cechą Haliny Korn jest całkowity brak obciążenia kulturą artystyczną. Stwierdzenie tego faktu, który bynajmniej nie jest krytyką, pozwala lepiej ocenić jej pewny instynkt artystyczny. Zbyt wielka kultura artystyczna może być dla artysty zgubna, często też jest źródłem eklektyzmu i manieryzmu. Tych cech w twórczości Haliny Korn nie dojrzy nawet „mędrca szkiełko i oko”. Twórczość ta jest samorodna, wyrosła jednak nie z gleby rodzinnej, lecz z bruku europejskiego. Jej życie, to żywioł schwytany na gorącym uczynku, na jakimś skrawku asfaltu czy posadzki: knajpa w dokach, kawiarnia w Soho, targ w Whitechapel, rzeźnik z połcią mięsa dekorator wystaw z gołymi manekinami, kobiety w łaźni. [...]. Halina Korn należy do charakterów, określanych jako palące się na wietrze świece. Ona grzeje, płonie. Jest to ogień, który zaraża, obejmuje innych. I to jest prawdopodobnie przyczyną jej zdumiewająco szybkiego sukcesu w dżungli współczesnego rynku artystycznego ${ }^{20}$.

Z kolei Aleksander Jackowski uważa, że twórczości artystki nie można porównywać do sztuki innych artystów naiwnych, jak choćby do Nikifora czy Rybkowskiego, tym samym nie można sklasyfikować jej jako artystki naiwnej ${ }^{21}$. Autor podkreślił, że ogromną rolę w jej życiu artystycznym odegrało środowisko, w którym żyła, szczególnie zaś obcowanie $z$ malarstwem męża ${ }^{22}$. Jackowski uważa zatem, że prostota wyrazu dzieł malarki była świadomym i zamierzonym elementem jej twórczości ${ }^{23}$. Można by pokusić się o polemikę z Jackowskim i zapytać, czy aby na pewno osoba, która nie miała wykształcenia artystycznego, nigdy nie ćwiczyła swojej ręki w rysunku i nie potrafiła poprawnie oddać perspektywy, świadomie czy też umyślnie stylizowała swoje prace na „prymitywne”? O pewnej manierze, stylizacji czy też o zamierzonych działaniach plastycznych można przecież mówić w przypadku artystów, mogących pochwalić się doskonałą sprawnością rysunkową i świetnym opanowaniem warsztatu rysowniczego. Za przykład można podać choćby doskonałego technicznie Picassa, który z pełną świadomością i premedytacją porzucił wszelkie proporcje i perspektywę na rzecz zniekształceń czy uproszczeń ${ }^{24}$. W przypadku twórczości Korn trudno mówić o jakiejkolwiek świadomej stylizacji czy „zamierzonej prostocie”, ponieważ prostota i jej charakterystyczny styl wynikały z braku umiejętności, nieporadności i braku profesjonalnego wykształce-

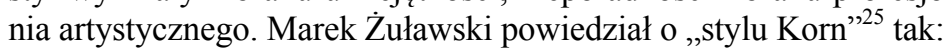

Halina Korn zaczęła malować jako osoba dorosła i dzięki temu, że nigdy nie przeprowadzała regularnych studiów akademickich zachowała całą spontaniczność widzenia i prawie dziecięcą naiwność ręki [...]. Zagadnienia kolorystyczne Halina rozwiązuje

${ }^{19}$ AE/HK-Ż, list H. Korn do M. Żuławskiego, 16 maja 1950.

${ }^{20}$ H. Heinsdorf, Żarliwość Haliny Korn, Tydzień Polski 1964 nr 46, s. 8.

${ }^{21}$ A. Jackowski, Sztuka zwana naiwna, s. 68.

${ }^{22}$ Tamże.

${ }^{23}$ Tamże.

${ }^{24}$ P. Szubert, Picasso i Kubiści, [w:] Sztuka Świata, red. W. Włodarczyk, t. 9, Warszawa 1996, s. 77-88.

${ }^{25}$ Określenie funkcjonujące $\mathrm{w}$ środowisku londyńskich handlarzy sztuki, przytoczone przez Stefanię Zahorską w recenzji do wystawy Haliny Korn; zob.: [Stefania Zahorska] St. Z., Halina Korn w „, Galery One”, Dziennik Polski i Dziennik Żołnierza 1960 nr 46, s. 3. 
z podobnie dziecinną odwagą: kolory które kładzie obok siebie zastraszyłyby najbardziej uczonego malarza, to znaczy, że bał by się ich użyć; ona kładzie je obok siebie $\mathrm{z}$ nieuświadomioną brawurą i siedzą mocno, trzymają się dobrze i dają niezwykłe efekty ${ }^{26}$.

Halina Korn żyła w środowisku artystycznym, obcowała z dziełami „,wielkich mistrzów”, znała sztukę Matisse'a, Modiglianiego, Picassa, Miro, Dalego; doskonale orientowała się w sztuce nowoczesnej, wraz z M. Żuławskim przygotowywała sprawozdania z wystaw, czytane na antenie Sekcji Polskiej BBC ${ }^{27}$. Jej twórczość jest jednak odrębna, nie dostrzeżemy tu naśladowania innych artystów - ani pod względem formalnym, ani w wyborze tematyki, dzięki czemu wymyka się wszelkim klasyfikacjom i próbom przyporządkowania jej do jakiejkolwiek grupy artystów. Podczas wizyty w Paryżu, po obejrzeniu wystawy Henri Matisse'a, zafascynowana jego malarstwem, napisała do męża w maju 1950 roku: ,[...] zaczynam przemyśliwać o rysowaniu jedną linią, ale się boję, że mi się nie uda, bo to trudniej jak paćkać po mojemu"28. Warto podkreślić, że Korn była artystką samorodną i, co ważne, zupełnie pozbawioną kompleksów artystycznych, które mogłyby wynikać $\mathrm{z}$ braku artystycznego wykształcenia.

Analizując twórczość artystki, można śmiało postawić tezę, że Halina Korn była malarką i rzeźbiarką „toczącego się wokół niej życia”, gdyż, jej zdaniem, każdy jego aspekt wart był uwiecznienia. W katalogu do wystawy w Traverse Theatre Gallery z 1964 roku Korn napisała:

\begin{abstract}
Lubię malować, kocham zapach farby i terpentyny. Kocham barwy żywe, zamiłowanie prawdopodobnie odziedziczone po ojcu, który spędzał swoje soboty i niedziele na malowaniu na czerwono, zielono i złoto wszystkiego, co mu wpadło w ręce. Tematy dla obrazów znajduję wszędzie, włóczą się one za mną i często muszę je zapisywać w obawie, że zapomnę. Nigdy nie rysuję na miejscu, tylko obserwuję na miejscu, a potem rysuję z pamięci. Kocham wszystko, co można malować. Kocham więc ludzi, ale nie ludzkość przecież ludzkości nie można malować. Ale można malować targi uliczne w Whitechapel — i na Boga, jak piękne są tłuste pośladki przekupek! Dla mnie akt akrobaty w cyrku nie jest mniej dramatyczny, niż ukrzyżowanie, a garstka twarzy u Lyonsa jest równie piękna, jak wiązanka kwiatów. Krajobraz Kilburn High Road daje mi tyleż radości, co najbardziej malowniczy widok włoski. Nie szukam ani piękna ani brzydoty. Nie pobierałam ortodoksyjnej nauki malarstwa. Mój mąż — malarz nauczył mnie jedynie dwóch rzeczy: „Dbaj o czystość pędzli i nie próbuj malować jak inni”. Usłuchałam jego rady ${ }^{29}$.
\end{abstract}

Fascynacja sztuką zrodziła się dzięki zrządzeniu losu. Halina Korn zachorowała i długo musiała leżeć w łóżku. Mieszkała już wówczas z Markiem Żuławskim w Londynie. Nie mogąc stale towarzyszyć swojej żonie, artysta ustawił na łóżku stelaż, a wręczając jej pędzle i farby, zachęcił, by coś namalowała. Dzięki temu prozaicznemu zdarzeniu obudziła się w niej niezwykła istota twórcza. Sztuka wypełniła całe — jakże nieszczęśliwe - życie artystki.

Niewłaściwym byłoby w przypadku Korn analizowanie jej twórczości w oderwaniu od życia. Można śmiało postawić tezę, że jedno wynikało z drugiego — sztuka w y n i k ała z życia i życie tr w ał o dzięki sztuce. Kiedy życie „,przyniosło” jej sztukę, stała się ona jej całym światem. Korn żyła dzięki sztuce i dla niej; stała się ona odskocznią od trudnej do zniesienia sytuacji małżeńskiej. Sztuka ją umacniała, dzięki

\footnotetext{
${ }^{26}$ Archiwum Emigracji w Toruniu, Archiwum Marka Żuławskiego, M. Żuławski, „Round the Galleries No 52", mps., k. 4.

${ }^{27} \mathrm{~Np}$. AE/MŻ/H. Korn, „Round the Galleries”, mps, [1956] k. 5.

${ }^{28}$ AE/HK-Ż, list H. Korn do M. Żuławskiego, 5 maja 1950.

${ }^{29}$ F. Topolski, M. Żuławski, Halinka, s. 5.
} 
niej widziała sens egzystencji, ponieważ mogła dostrzec na horyzoncie swojego życia cel. Dzięki sztuce czuła się ważna i potrzebna.

Biorąc tym samym pod uwagę biogram artystki, szczegółowo opracowany przez Joannę Krasnodębską w artykule „,Angielka w Paryżu”. Listy Haliny Korn-Żuławskiej do męża (maj-czerwiec 1950) ${ }^{30}$, można dostrzec, że sztuka była dla niej formą wyzwolenia własnych pragnień, ucieczką od trudów dnia codziennego oraz rodzajem terapii i ,przepracowania” traumy wojennej ${ }^{31}$, która wywarła olbrzymie piętno na jej osobowości. Mówiąc jednak o traumie wojennej, nieuzasadnionym jest myślenie, że malarka doświadczyła tragedii wojny osobiście. Mowa tu jest raczej o doświadczeniu traumy pośrednio, ponieważ dotyczyła ona utraty najbliższych, których Niemcy wymordowali $\mathrm{w}$ trakcie wojny. Warto w tym miejscu zauważyć, że żydowskie pochodzenie artystki nie miało wpływu na tematykę jej prac. Korn została wychowana w tradycji polskiej, o czym świadczy jej pamiętnik Wakacje kończa się we wrześniu, w którym szczegółowo przytoczyła i opisała okres dzieciństwa. Trudno też znaleźć jakiekolwiek jej prace, nawiązujące do tematyki żydowskiej lub Szoa ${ }^{32}$.

W sierpniu 1939 roku Halina Korngold (takie nazwisko wówczas nosiła) wyjechała na wakacje do Paryża i St. Malo (Bretania). Tam zastał ją wybuch II wojny światowej. Wraz z Markiem Żuławskim udała się do Paryża, a później Angers, gdzie podjęła pracę w agendach Rządu RP na Uchodźstwie ${ }^{33}$. O utracie rodziny, która została w pogrążonym wojną kraju, dowiedziała się dopiero w 1946 roku, gdy mieszkała już z Żuławskim w Londynie $i \mathrm{w}$ pełni realizowała się jako artystka ${ }^{34}$. Informacja ta wywołała u niej tak duży stres, że przeobraził się on w załamanie nerwowe, po którym pierwszy raz trafiła do szpitala ${ }^{35}$. Lekarze zdiagnozowali u malarki chorobę maniakalnodepresyjną ${ }^{36}$. U podstaw oceny twórczości Korn stoi zatem diagnoza lekarska, która zdeformowała patrzenie na obrazy. A jeśli — co staram się wykazać dalej — Korn nie była chora psychicznie? Depresja, którą u niej stwierdzono, nie powinna być podstawą do kwalifikowania jej jako osoby chorej psychicznie. Załamanie nerwowe zostało wywołane przez informację o utracie rodziny, a powtarzające się późniejsze „ataki” złości były efektem narastającego konfliktu z mężem, nie zaś skutkiem choroby, o czym mogłoby świadczyć późniejsze wyznanie Żuławskiego:

nie umiałem Halince zapewnić ani ekonomicznej stabilizacji, ani emotional security, której tak bardzo potrzebowała. Jej pozycja była stale zagrożona. Nie czuła się ani jedyna, ani nawet specjalnie potrzebna w moim życiu. [...] zaraziłem ją problemami, na które nie ma odpowiedzi ${ }^{37}$.

${ }^{30}$ J. Krasnodębska, ,Angielka w Paryżu”. Listy Haliny Korn-Żuławskiej do męża (majczerwiec 1950), Archiwum Emigracji. Studia - Szkice - Dokumenty 2012 z. 1-2 (16-17), s. $156-174$.

${ }^{31}$ S. Davidson, The Psychosocial Aspects of Holocaust Trauma in the Life Cycle of Survivor Refugees and Their Families, [w:] R. Baker, L. Kirkley, The Psychosocial problems of refugees, London 1983, s. 21-32.

${ }^{32}$ Dotyczy to także prac podarowanych londyńskiej Ben Uri Art Gallery; zob.: Jewish Artists. The Ben Uri Collection. Paintings, Drawings, Prints and Sculpture, ed. by W. Schwab, J. Weiner, London 1994, s. 60.

${ }^{33} \mathrm{http}: / / w w w . m u z e u m . u m k . p l / s z t u k a \_p o l s k a / h a l i n a-k o r n / k a l e n d a r i u m \# 1930$

${ }^{34} \mathrm{http}: / /$ www.muzeum.umk.pl/sztuka_polska/halina-korn/kalendarium\#1940

${ }^{35}$ Tamże.

${ }^{36}$ Por.: M. Żuławski, Studium do autoportretu, s. 50.

${ }^{37}$ Tamże, s. 215. 
Nie znamy dokumentacji medycznej. Istnieją jednak przynajmniej dwa niepodważalne dowody, świadczące o tym, że Halina Korn nie była osobą chorą psychicznie: sztuka, którą po sobie pozostawiła, będąca spójną z tym, co artystka mówiła i pisała, oraz jej liczna korespondencja z mężem i przyjaciółmi, w której jest świadoma swoich uczuć i emocji.

Jednak z listów artystki do Żuławskiego, pisanych z Angers w trakcie wojny, wynika, że już samo rozdzielenie $\mathrm{z}$ najbliższymi było dla niej bardzo trudnym doświadczeniem, powodującym depresyjne, z czasem nasilające się nastroje: „,...] Boże mój czy ja już całe życie będę się tak tułać sama bez domu, bez swoich, bez nikogo bliskiego",38 oraz:

Jakie to straszne Marku, być tak szalenie samą na świecie. W tym Angers odczuwam to coraz dotkliwiej i choć staram się nie poddawać i topić chandry w pracy — mimo to są takie godziny przedwieczorne, po skończonym biurze, kiedy jest bardzo źle i strasznie ciężko i samotnie. Drepcze się wtedy przez puste zazdrośnie pozasłaniane prowincjonalne miasto [...] idzie się na samotny obiad [...], a potem wdrapuje się na trzecie piętro, do miłego wprawdzie, ale tak strasznie obcego i pustego pokoju i tęskni się strasznie do swoich. [...] wiem sama jak straszna jest świadomość, że się jest zupełnie samemu [...] i wolne chwile w Angers na nic się nie przydają... chyba na to, żeby się gnębić myślą o swoich ${ }^{39}$.

Kilka miesięcy później napisała:

[...] nie mam zupełnie cierpliwości ani chęci do przebywania z ludźmi... chciałabym być tu z Jadzią i ze swoimi - reszta budzi we mnie coś w rodzaju żalu i niechęci, że to nie one. [...] moralnie — różnie, miewam okresy takiego upadku i takiej szalonej tęsknoty za Wawą i moimi dwiema kochanymi babami, że wydaje mi się, że ani chwili dłużej nie wytrzymam. Teraz właśnie taki czas przeżywam, bo wiosna pachnie tak jak nasza i po prostu wyrywa człowiekowi serce ${ }^{40}$.

W maju 1940 r. napisała ponownie:

[...] poczucie oddalenia od moich najbliższych i najdroższych wzmogło się stukrotnie w ostatnich dniach. Myślę o nich jak o czymś nierealnym i odnajduję jakieś zapomniane słowa modlitwy za nich i za to, żeby ich kiedyś zobaczyć... ${ }^{41}$.

Wydarzenia te w znaczący sposób naznaczyły osobowość Haliny Korn. Informacja o utracie rodziny, o której z taką czułością napisała w swoim pamiętniku lat dziecięcych $^{42}$, stała się czymś w rodzaju punktu granicznego czy zwrotnego w jej życiu. W wyniku traumy pojawiały się u artystki poważne zaburzenia nastroju i były one odpowiedzialne za ogromne cierpienia $\mathrm{z}$ powodu występujących objawów. Według badaczy, traumatyczne doświadczenia zaburzają normalną regulację stanów emocjonalnych, systematycznie wywołując przerażenie, gniew, stany dysforyczne, stany za-

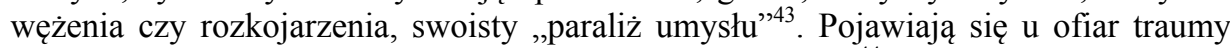
stany zagubienia, pustki i niewypowiedzianej samotności ${ }^{44}$. Wszystkiego tego do-

\footnotetext{
${ }^{38}$ AE/HK-Ż, list H. Korn do M. Żuławskiego, Angers, 23 listopada 1939.

${ }^{39}$ AE/HK-Ż, list H. Korn do M. Żuławskiego, Angers, 27 listopada 1939.

${ }^{40}$ AE/HK-Ż, list H. Korn do M. Żuławskiego, Angers, 23 lutego 1940.

${ }^{41}$ AE/HK-Ż, list H. Korn do M. Żuławskiego, Angers, 18 maja 1940.

${ }^{42}$ H. Korn Żuławska, Wakacje Kończa się we wrześniu.

${ }^{43}$ S. Davidson, The Psychosocial Aspects of Holocaust, s. 21-32.

${ }^{44}$ Tamże.
} 
świadczała Korn na co dzień, o czym wspomniał Żuławski w Studium do autoportretu, pisząc, że osobowość Halinki bardzo się zmieniła, przejawiała skrajne zachowania z euforii wpadała w skrajną rozpacz i „załamywała ręce” z najbanalniejszych często powodów, co wcześniej było do niej niepodobne ${ }^{45}$.

I choć artystka nie doświadczyła urazów fizycznych w wyniku wojny ani strachu o własne życie, z którymi borykali się jej najbliżsi, to została naznaczona traumą utraty rodziny. Świadomość, że przeżyła tylko ona, wywoływała wyrzuty sumienia ${ }^{46}$. Mogły być one spowodowane również tym, że nie była $\mathrm{w}$ stanie pomóc swojej rodzinie, o czym napisała w liście do Marka w kwietniu 1940 roku:

[...] marzę o tym, by mogły być tutaj razem ze mną. A to niemożliwe, niemożliwe nie mam dość pieniędzy, żeby je tu sprowadzić, nie mówiąc już o tym, że nie wiem za co bym je tutaj utrzymała [...]. Gnębi mnie to strasznie, jak również i myśl, że moja pomoc może do nich nie dociera i, że tak strasznie mało mogę dla nich zrobić. W ogóle źle ze mną ostatnio psychicznie - przestałam być „dzielna”, tęsknię tak strasznie za Wawą, za Jadzią i Ciotką, że mam momenty najzupełniejszego załamania ${ }^{47}$.

Należy wspomnieć, że choć artystka pośrednio doświadczyła traumy, związanej z Szoa, to nie tworzyła sztuki, naznaczonej tragedią narodu żydowskiego, jak miało to miejsce w przypadku licznych artystów żydowskich: Jonasza Sterna, Józefa Szajny, Izaaka Celnikiera, Samuela Baka, Jacques'a Lipchitza, Menashe Kadishmana, Marka Rotko czy Marka Oberländera ${ }^{48}$. W sztuce Korn trudno doszukiwać się tego rodzaju ,przepracowywania traumy". Całkowite oddanie się malarstwu i rzeźbie było dla artystki formą wyzwolenia i ucieczki od samotności. To, co odróżnia jej malarstwo od twórczości wymienionych artystów, to malowanie życia, które ją otaczało, skupianie się na otaczającej ją codzienności. Nie odnajdziemy w jej sztuce odniesień do cierpienia, przemocy czy śmierci, jej sztuka była prosta, nieambiwalentna. I choćby dostrzeżenie tego faktu pozwala sądzić, że to nie trauma wojenna odbiła najważniejsze piętno w jej życiu, bo przecież jej nie doznała, ale poczucie osamotnienia, będące konsekwencją utraty bliskich, którzy tej traumy doświadczyli. Nie ma więc podstaw, by twierdzić, że Szoa miało wpływ na jej sztukę lub też na „,narodziny” Korn jako artystki, ponieważ zaczęła tworzyć na długo przed informacją o śmierci rodziny.

Jan Wiktor Sienkiewicz stawia tezę, że dzięki sztuce artystka stale dokonywała „oswajania świata”, podobnie jak robili to artyści niepełnosprawni intelektualnie ${ }^{49}$. Owo oswajanie rzeczywistości, będącej dla chorych umysłowo źródłem odrzucenia i bólu, miało polegać na otwarciu się na otaczający świat, na uzewnętrznieniu i wizualizowaniu, za pomocą sztuki, swojego świata wewnętrznego, co umożliwiało im nabranie wiary w siebie. Sienkiewicz pyta, jak zakwalifikować, rozpoznać i wartościować prace, które wyszły spod pędzla i dłuta osób, które przez pierwszą część swojego życia funkcjonowały w tak zwanym naszym świecie i z powodu przeżyć czy nieszczęśliwych wypadków resztę swojej — często smutnej — egzystencji spędzili, balansując na granicy świata zdrowych i świata chorych; na granicy sprawności i niepełnosprawności

${ }^{45}$ M. Żuławski, Studium do autoportretu, s. 216-217.

${ }^{46}$ Tamże, s. 213.

${ }^{47}$ AE/HK-Ż, list H. Korn do M. Żuławskiego, Angers, 10 kwietnia 1940.

${ }^{48}$ M. A. Supruniuk, Kadisz za sztetl, [w:] Życie sztetla w sztuce Żydów polskich na świecie $w X X$ w. Prace ze zbiorów Biblioteki Uniwersyteckiej, Archiwum Emigracji oraz Towarzystwa Przyjaciół Archiwum Emigracji, [praca zbiorowa], Toruń 2016, s. 16.

${ }^{49}$ J. W. Sienkiewicz, Sztuka oswajania świata, s. 123-151. 
umysłowej $?^{50}$ Autor umieszcza twórczość Korn wśród artystów, sytuujących się „na granicy”, czyli takich, którzy z różnych przyczyn losowych balansują na pograniczu zaburzeń i zdrowia psychicznego ${ }^{51}$. Teza ta wydaje się kontrowersyjna; jak sam badacz zauważył, trudno zaklasyfikować Korn do jakiejkolwiek grupy artystów - ludzi chorych, zdrowych, artystów naiwnych czy prymitywnych — ponieważ żadne z tych określeń nie będzie w stu procentach odnosiło się do sztuki i osoby Haliny Korn. Artystka wymyka się więc wszelkim kategoryzacjom i już sam fakt próby umieszczenia jej w grupie artystów, oscylujących pomiędzy pełnosprawnością a niepełnosprawnością intelektualną, jest dyskusyjny i wydaje się znacznym uproszczeniem. Jak zaznaczyłam wyżej, wszystkie próby interpretacji jej twórczości były tworzone w oparciu o błędne założenie, że Korn była chora psychicznie. Warto w tym miejscu postawić pytanie w którym miejscu, w jakich obrazach czy rzeźbach ta rzekoma choroba się ujawnia? Gdzie i czy w ogóle można ją dostrzec?

Rozsądne wydaje się uznać, że sztuka stanowiła dla artystki formę ucieczki od trudnej codzienności, była czymś, czemu mogła poświęcić swoje myśli, zaangażowanie i czas, czymś, w czym odnalazła ukojenie i mogła wyrazić swoje odczucia i pragnienia. I choć najbliższą jej osobą był mąż - Marek Żuławski, to relacja ta nie pozwalała malarce wypełnić pustki po wymordowanej rodzinie. Należy podkreślić fakt, że Żuławski odegrał w jej życiu osobistym i artystycznym kluczową rolę - to dzięki niemu zaczęła malować, on ją wspierał, doceniał i umocnił jej wartość jako artystki, pomagał niemal we wszystkich artystycznych przedsięwzięciach. Jednocześnie będąc jej mężem, nie poświęcał tyle czasu i uwagi, ile potrzebowała, by zachować równowagę psychiczną i emocjonalną. Jej samotność stała się siłą napędową do tworzenia. Sztuka odrywała ją od codzienności, zajmowała, pochłaniała myśli i czas, stała się czymś w rodzaju wypełnienia „pustego miejsca”, ${ }^{2}$, o którym napisała wybitna psychoanalityczka polskiego pochodzenia, Hanna Segal. Aby opisać to zjawisko, Segal przytoczyła w swojej pracy spostrzeżenie innej uczonej, Melanie Klein, która omówiła przypadek szwedzkiej malarki Ruth Kjar. Artystka ta, cierpiąca na powracające stany depresyjne, miała nieustanne poczucie, że została pochłonięta przez puste miejsce $\mathrm{w}$ swoim wnętrzu, które powstało na skutek usunięcia ze ściany jej mieszkania jednego z wiszących tam obrazów — „na ścianie zostało puste miejsce, które w niewyjaśniony sposób zdawało się powiązane z pustym miejscem w jej wnętrzu" ${ }^{\text {"53 }}$. Biograf artystki spostrzegł, że niemożność tolerowania pustego miejsca na ścianie zmusiło Kjar do tego, że sama zaczęła malować ${ }^{54}$. W przypadku Korn „pustym miejscem” w jej życiu była relacja z Markiem Żuławskim, sztuka zaś stała się formą wypełnienia tej pustki.

Relacje małżeńskie Korn i Żuławskiego wydają się kluczem do jej twórczości, dlatego też warto je omówić. Pozostając w związku małżeńskim, Korn dręczyło wspomniane wcześniej poczucie ciągłego osamotnienia, wynikające z tego, że Żuławski nie dawał jej potrzebnego wsparcia, gdy najbardziej go potrzebowała, czyli w momencie, kiedy dowiedziała się o utracie bliskich i zaczęła cierpieć na - pogłębiającą się na skutek jego zachowań - depresję; świadomość, że kochany mąż poświęca wiele czasu innym kobietom, stała się dla niej źródłem skrajnych emocji - z jednej strony był miłością jej życia: „Moja świadomość szczęścia funkcjonuje tylko w oparciu o Cie-

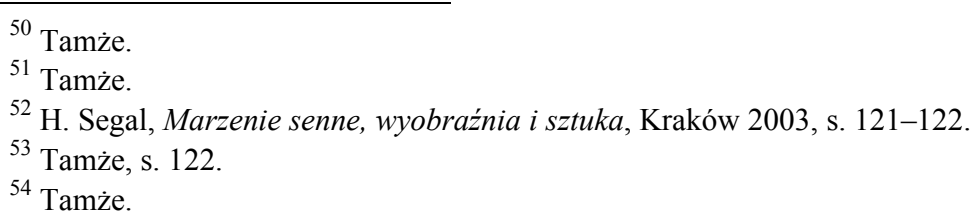


bie" ${ }^{\text {55 }}$ z drugiej zaś z czasem zaczęła go nienawidzić za krzywdę, jaką jej wyrządzał tym, iż nie była jedyną kobietą $\mathrm{w}$ jego życiu:

You made me suffer too much and I don't love You anymore. And I do hate the girl Trebble. She has stolen my husband whether he was good or bed. She is the cause of my having to face lonely old age she ruined what we, two creative artists, have built together during nineteen years of our married life. [...] And Marek, there is nowway back I wait to forget that you ever existed. And I am going to, I promise! ${ }^{56}$.

O tym, jak ważny był w jej życiu Marek Żuławski, napisała wielokrotnie w korespondencji do niego. Przytoczmy fragment listu napisanego w maju 1946 roku:

Chałupa bez Ciebie, synku, poza tym, że smutna jak nie wiem co, jest bardzo trudną sprawą. Wszystkie mechaniki bez Ciebie są okrutnie wrogie bez Twojej pomocy najmądrzejszej i zawsze w porę, wszystko ciężkie i trudne, bez Twojej aprobaty i najśliczniejszej przychylności — życie jest czymś nie do zniesienia. Już teraz wiem, że to tylko przez Ciebie, tylko za Twoją przyczyną — jestem wytrwała i uśmiechnięta, tylko przy Tobie nie ma wątpliwości czy coś jest złe czy dobre, tylko przy Tobie jestem pewna swego zdania o sprawach i ludziach — tylko Twoja aprobata jest najwyższą zdobyczą $^{57}$.

O dręczącym ją nieustannie poczuciu samotności wspominała niemalże w każdym liście do męża, ale też do przyjaciół. W 1947 roku pisała do męża:

Wszystko jest źle wszystko jest niedobrze, jedyną zaporą przed wrogością świata ludzi i rzeczy martwych jesteś Ty... [...] jakoś zapełniam czas w którym wyrwa zrobiona przez Twoją nieobecność jest większa od największej przepaści na świecie ${ }^{58}$.

Wiele lat później, w pełnym dramatu liście ze szpitala, zauważała:

siedzę samotna jak parszywy pies i czekam pójścia do łóżka żeby się wypłakać, że po utracie Stefana, którego szaleńczo kochałam i Jadzi w mękach spalenia na żywo i Adama, który kiedyś stałby mi się prawdziwym synem jestem rozbita i w Tobie jedynym widzę cały świat ${ }^{59}$.

W kwietniu 1965 roku zwierzyła się przyjacielowi, Krzysztofowi Dowgiałło:

Tak mi się dobrze maluje i powinnam być a właściwie prawie jestem szczęśliwa, choć brak mi najważniejszej rzeczy w życiu — prawdziwej bliskości kogoś bardzo kochanego. Jakiś dziwny kryzys przeżywamy w naszym życiu z Markiem - i to nie dziwki, nie drobiazgi, tylko jakaś straszliwa zmiana naszych stosunków. Nie umiem dobrze tego określić i nie wiem jak się to wszytek skończy. Może dobrze, może źle... I także nie wiem co by było źle czy dobrze: czy być razem z goryczą w sercu i duszy czy spróbować życia osobno żeby się przekonać co dla siebie naprawdę znaczymy. Wiem że maluje mi się jak jeszcze nigdy, wiem że coraz więcej ludzi mnie potrzebuje i uznaje pod każdym względem i wiem że nigdy nie doczekam się tego od tych, którzy powinni m być najbliżsi ${ }^{60}$

${ }^{55}$ AE/HK-Ż, list H. Korn do M. Żuławskiego, 16 maja 1950.

${ }^{56}$ AE/HK-Ż, list H. Korn do M. Żuławskiego, 5 lipca 1959.

${ }^{57}$ AE/HK-Ż, list H. Korn do M. Żuławskiego, 27 maja 1946.

${ }^{58}$ AE/HK-Ż, list H. Korn do M. Żuławskiego, 3 października 1947.

${ }^{59}$ AE/HK-Ż, list H. Korn do M. Żuławskiego, Horton Hospital (Epsom), 13 października 1966.

${ }^{60}$ AE/HK-Ż, list H. Korn do Krzysztofa Dowgiałło, 29 kwietnia 1965. 
Lektura korespondencji pozwala mieć pewność, że skomplikowana relacja z Żuławskim była nieustannym źródłem lęków dla nadwyrężonej po utracie bliskich psychiki artystki. Pierwsze lata ich związku utwierdziły Korn w przekonaniu, że Żuławski oprócz tego, iż jest jej mężem, jest także jej najlepszym przyjacielem i „,bratnią duszą” — czego dowodzą listy, pełne ciepła i czułości, pisane do niej przez Marka:

Co do mnie to wiem, że bez Ciebie widzę wszystko jakoś jakby z wielkiej odległości, jakby przez odwrotną stronę lunety. Bez Ciebie byłbym najsmutniejszym człowiekiem na ziemi. Jesteś moją kotwicą, która utrzymuje mnie w kontakcie z rzeczywistością. To są wyznania bardzo intymne i tylko dla Ciebie, ale bez Twojej bliskości nawet już nie interesują mnie facetki” ${ }^{61}$ oraz późniejszy, pełen troski i otuchy list wysłany z Nowego Jorku: „Miła kochana staraj się wszelkimi siłami być zdrowa i dobrej myśli — pamiętaj, że nie jesteś sama na świecie i, że ja zawsze będę się Tobą opiekował dopóki Ty nie powrócisz do zdrowia na tyle, żebyś się znowu zaczęła mną opiekować ${ }^{62}$.

W codziennym życiu obydwoje spędzali ze sobą niewiele czasu - Marek był najczęściej poza domem (oprócz pracy wiele czasu pochłaniało mu życie towarzyskie), sporo też podróżowali — jednak zazwyczaj każde osobno, wspólnych wyjazdów było zdecydowanie mniej. Ta niemalże ciągła rozłąka zaczęła z czasem bardzo doskwierać artystce, która odczuła samotność boleśnie, niemal fizycznie. Dzięki zachowanej korespondencji widać, jak wraz z upływem lat narastało w niej uczucie osamotnienia, potęgowane przez świadomość, że nie jest jedyną kobietą w życiu swojego męża. Można zaryzykować stwierdzenie, że dopóki była młoda i jej uroda kwitła, starała się wypierać świadomość bycia zdradzaną; miała dystans do niewierności męża, o czym świadczą drwiny z jego postępowania: „Czy dużo dziewuch lata do Ciebie? Czy dobrze być nieżonatym?" ${ }^{\text {"63 }}$. Warto podkreślić, że zamiłowanie Żuławskiego do kobiet nie było też tematem tabu we wczesnych latach ich małżeństwa, o czym można się przekonać dzięki listom Marka do Korn:

[...] w międzyczasie Czajk kazał mi pójść na dziwki i - skompromitowałem się z kretesem. Zdaje się, że na skutek tych zawracań głowy i leczenia, a także braku chędożenia przez dłuższy czas, popadłem w histeryczną impotencję. Moja neurastenia naprawdę miewa granice, bo i malować zupełnie nie mogę. [...] Cieszę się bardzo, że niedługo się zobaczymy, ale obym przedtem mógł trochę się połajdaczyć, byłbym o wiele milszy dla Ciebie... ${ }^{64}$.

Korn miała świadomość swojej urody, była kobietą adorowaną i pożądaną. Kiedy wraz $\mathrm{z}$ wiekiem oraz $\mathrm{w}$ wyniku nieudanych terapii elektrowstrząsami i leczenia farmakologicznego zaczęła tracić urodę, spotęgowało to poczucie lęku i cierpienie: „Była piękna. Więc kiedy zaczęła się starzeć, cierpiała bardziej niż inne kobiety” — pisał Żuławski ${ }^{65}$. Lęki te objawiały się głęboką zazdrością o męża i przewrażliwieniem, potęgowanym listami Marka:

[...] nie mogę i nie chcę być traktowany jak niewolnik, który musi się opowiadać gdzie i po co wychodzi z domu. Nie mogę i nie chcę być upokarzany przed obcymi i wymyślany w obecności robotników i posługaczek. Nie mogę i nie chcę być przedmiotem ubolewań naszych przyjaciół - nie chcę musieć się wstydzić, że przez 20 lat nie umia-

\footnotetext{
${ }^{61}$ AE/HK-Ż, list M. Żuławskiego do H. Korn, 4 października 1947.

${ }^{62}$ AE/HK-Ż, list M. Żuławskiego do H. Korn, Nowy Jork, 23 września 1967.

${ }^{63}$ AE/HK-Ż, list H. Korn do M. Żuławskiego, 25 lutego 1950.

${ }^{64}$ AE/HK-Ż, list M. Żuławskiego do H. Korn, 31 maja 1949.

${ }^{65}$ M. Żuławski, Studium do autoportretu, s. 213.
} 
łem wychować sobie z Ciebie lojalnego przyjaciela, któryby znając moje i twoje własne wady potrafił wznieść się na jakiś cywilizowany poziom tolerancji. Nie mogę jednym słowem żyć pod jednym dachem z wrogiem i szaleńcem. Nie jesteśmy już młodzi i o seksie w naszych stosunkach (tak jak w każdym małżeństwie po tylu latach) mowy być nie może $e^{66}$.

Kiedy Żuławski zaczął okazywać jej coraz większą obojętność, wzbudzając w niej poczucie odtrącenia, ,histerie” stały się codziennością Korn. Z czasem zamieniły się w nienawiść do męża za cierpienie, które sprawiał jej swoim zachowaniem.

Korn oczekiwała od męża wierności, lojalności, szacunku i wsparcia, co podkreślała wielokrotnie:

Nie zarzucaj mi proszę głupoty i szaleństwa wyjdź naprzeciw i dopomóż mi odzyskać spokój i zaufanie i odbudować jakieś nasze współżycie [...]. Chcę być lojalna wobec Ciebie i tego samego pragnę od Ciebie w stosunku do mnie ${ }^{67}$.

O co chodzi, gdzie jestem, czy mogę znów spokojne myśleć kiedy mnie zostawiasz samą wieczorem, ,że idziesz na dziwki a nie do kogoś kto beze mnie zginie" - ja nie chcę i nie umiem w ten sposób dzielić się Tobą i zrezygnowałam z wielu rzeczy, ale jeśli mamy podpisywać formularz - to wymiennie: ,Ja Marek Żuławski oświadczam, że zerwałem z Miss Trebble raz na zawsze, że nie będę nazywał mojej żony kretynką ani obrażał jej w inny sposób, że w zamian za to że sam podróżuję i sam używam przyjemności życia daję jej swobodę życiowego działania... I że nigdy nie będę jej wymawiał tego, że jej daję utrzymanie, które się jej prawnie należy..., bo wiem, że to straszliwie dotyka jej ambicję i czyni z niej w jej pojęciu darmozjada, zawalidrogę i niedołęgę (patrz wyrzuty sumienia w break downach)". Wtedy ja podpiszę Twój formularz i zaczniemy nowe życie pełne przyjaźni i szczęścia ${ }^{68}$.

„Histerie” i wybuchy zazdrości powodowały, że Marek notorycznie umieszczał ją w szpitalu dla chorych psychicznie, obarczając ją odpowiedzialnością za pogorszenie ich relacji oraz za rozkład małżeństwa. Pobyt w szpitalu psychiatrycznym jako „kara” za złe zachowanie - wybuchy gniewu, awantury — jednocześnie uzasadniany był przez Marka jako absolutna konieczność i przywołanie Haliny do porządku oraz do stanu równowagi i zdrowia. W liście z lipca 1962 roku pisał do żony:

[...] jeżeli natomiast będziesz robić awantury, to przymusowy twój pobyt w szpitalu zostanie naturalnie przedłużony aż dopóki nie będziesz się zachowywać jak normalny człowiek, który pragnie być zdrowy ${ }^{69}$.

Innym razem dodawał:

Błagam Cię nie zmuszaj mnie do odebrania Cię ze szpitala dopóki nie będziesz się nadawała do współżycia i spełniania swoich zadań jako żona i pani domu ${ }^{70}$.

W relacjach, które ulegały głębokiemu pogorszeniu wraz z postępami „choroby”, artystka początkowo czuła się winna i odpowiedzialna za „krzywdę”, którą wyrządzała mężowi, będąc zbyt mało tolerancyjną. W listach ze szpitala pisała: „odpoczywaj od moich złych nastrojów. Myślę, że tego Ci naprawdę potrzeba więcej niż czegokolwiek

\footnotetext{
${ }^{66}$ AE/HK-Ż, list M. Żuławskiego do H. Korn, 21 maja 1961.

${ }^{67}$ AE/HK-Ż, list H. Korn do M. Żuławskiego, 26 maja 1961.

${ }^{68}$ AE/HK-Ż, list H. Korn do M. Żuławskiego, 4 września 1961.

${ }^{69}$ AE/HK-Ż, pocztówka wysłana przez M. Żuławskiego do H. Korn, 16 lipca 1961.

${ }^{70}$ AE/HK-Ż, list M. Żuławskiego do H. Korn, 8 października 1966.
} 
w tej chwili. [...] staram się trzymać jak najlepiej”"71 i „, raz jeszcze widzę czym jest dla mnie nasz wzajemny stosunek, żebym tylko mogła odzyskać zdrowie i równowagę, byłoby nam teraz dobrze razem. Całuję Cię naj najmilszy i jestem szalenie bez Ciebie zagubiona. Tęsknię i nie mam żadnego miejsca na świecie" ${ }^{, 72}$. Z czasem, kiedy pobyty W szpitalu stawały się częstsze, korespondencja jej stawała się coraz bardziej dramatyczna:

[...] nikt nie ma prawa zatrzymywać mnie tutaj wbrew naszej woli. [...] błagam na wszystkie świętości, na matkę Chrystusa zabierz mnie stąd. [...] Marku jedyny zabierz mnie stąd, wiesz jak Cię kocham i wiesz, że zrobię co karzesz. Marku, ratowałeś obcą Martę, ratuj Twoją żonę — błagam Cię na wszystko... ja nie jestem zła, Ty wiesz miałam tylko za dużo nieszczęścia — ja sobie sama poradzę jeśli będziesz chciał, tylko mnie stąd wyprowadź — błagam! [...] nie musimy być razem jeśli nie chcesz ${ }^{73}$.

Listy z lat 60. ze szpitala każą poddawać w wątpliwość zasadność uznania jej za chorą umysłowo. Widać to wyraźnie, gdy pisze:

Bardzo tęsknię za Tobą i za domem, życie tutaj jest zupełnym koszmarem. Ty sobie nie zdajesz sprawy na jakie wypadki się tutaj napotyka; jakie wrzaski budzą w nocy i na co wszystko osoba tak wrażliwa jak ja (powiedzmy prawdę — przewrażliwiona) musi patrzeć. Marku, napisz słówko, jeśli będziesz miał czas, ja noszę przy sobie Twoją kartkę, którą mi przysłałeś i raz po razie odczytuję, żeby nie stracić w tym wariackim piekle kontaktu ze światem i co najważniejsze $z$ Tobą ${ }^{74}$

oraz:

[...] nikt nie ma wyobrażenia jak ja się boję — i jak ta męka ma pomóc w rozwiązaniu groźnych problemów naszego życia i wyplątać mnie z tego wszystkiego co się narobi$\mathrm{to}^{75}$.

Listy te pokazują, jak bardzo cierpiała, będąc zamkniętą w szpitalu z osobami chorymi psychicznie, a eksperymentalne leczenie elektrowstrząsami nie przynosiło żadnych pozytywnych rezultatów, sprawiając, co grosza, że artystka stawała się coraz bardziej „wypalona” emocjonalnie, zanikał jej twórczy instynkt oraz miewała krótkotrwałe zaniki pamięci: ,[...] nie mogę sobie przypomnieć! Wszystko mam we łbie wyglancowane na gładko - pewnie to będzie świetne dla mej dalszej twórczości" "76. Z zachowanych archiwaliów i liczby namalowanych obrazów z czasów, kiedy często przebywała w szpitalach, wiadomo, że owo ,leczenie” było zabójcze dla jej twórczości, bo z czasem przestała malować zupełnie.

Pomiędzy kolejnymi, coraz częstszymi pobytami w szpitalu próbowała wszelkimi siłami odseparować się od męża, co ważne - była wówczas bardzo aktywna artystycznie, zabiegała o wystawy, wiele podróżowała, celem jej życia stała się wystawa w Nowym Jorku, który pretendował w owym czasie do bycia centrum artystycznego świata. Wszystko to, by udowodnić Markowi, że potrafi sobie bez niego artystycznie i prywatnie poradzić. Miała jednak gorzką świadomość zależności. W jednym z listów

\footnotetext{
${ }^{71}$ AE/HK-Ż, list H. Korn do M. Żuławskiego, 1 października 1947.

${ }^{72}$ AE/HK-Ż, list H. Korn do M. Żuławskiego, 8 października 1947.

${ }^{73}$ AE/HK-Ż, list H. Korn do M. Żuławskiego, 22 lutego 1950.

${ }^{74} \mathrm{AE} / \mathrm{HK}-\dot{Z}$, list H. Korn do M. Żuławskiego, 17 czerwca 1961

${ }_{75}$ AE/HK-Ż, list H. Korn do M. Żuławskiego, 13 listopada 1963.

${ }^{76}$ AE/HK-Ż, list H. Korn do M. Żuławskiego, York Clinic, 25 lutego 1950.
} 
prosiła: ,proszę Cię przyspiesz sprawę legalnej separacji i rozdzielenia naszego wspólnego życia fizycznego i moralnego jak najprędzej”,77, w innym natomiast:

Proszę Cię nie każ mi prosić raz jeszcze o pieniądze, które a) zaoferowałeś sam, które b) należą mi się jako twojej żonie. Chandryczenie się o te sprawy jest tak przykre, poniżające, że będę cierpieć głód i braki tutaj raczej, niż raz jeszcze Cię prosić ${ }^{78}$.

Potrzeba separacji wynikała $\mathrm{z}$ tego, że Żuławski stawał się dla niej coraz bardziej okrutny, o czym świadczą jego listy: „nie mam zamiaru być tyranizowany ani Twoją miłością ani Twoją wrogością i brakiem zrozumienia cudzych przyjemności" ${ }^{, 79}$ oraz:

[...] Nie widzę w nim [w liście otrzymanym od żony] żadnych rewelacji oprócz spóźnionego odkrycia że „nie sposób jest zabić 20 lat przeżytych razem”. Szkoda że do tego wniosku nie doszłaś wcześniej kiedy mogłaś ocalić jeszcze cały ogromny kapitał mojego przywiązania i serdecznej przyjaźni. Z pełnym poczuciem odpowiedzialności - za każde słowo muszę stwierdzić, że zrobiłaś WSZYSTKO co się da w naszych okolicznościach i w istniejącej sytuacji aby zabić te 20 lat wspólnego życia. Myślałem że taki był twój bohaterski plan — jeżeli nie, to zaprawdę jesteś najgłupszą kobietą jaką kiedykolwiek poznałem ${ }^{80}$.

W pełnym goryczy i wyrzutów, ale jednak niezwykle przemyślanym liście po angielsku $^{81}$, będącym podsumowaniem ich relacji oraz uzewnętrznieniem jej uczuć i emocji, napisała:

Our marriage was a happy one for you because you have had an obedient, loving, devoted and faithful wife. I was not happy because I wanted faithfulness, love and loyalty and I never had them. Several times I landed at the Clinic with nerves breakdowns - I am oversensitive, you know it and finally I was given psychoanalytical treatment to help me to understand myself and to put up with the problems of my married life. You became cruel and indifferent to me and the drama started. No need to repeat the tragic and trivial details of our life since august $2^{\text {nd }} 1957$ when I found the girl Trebble's lipstick on your bench her nighttie in our bed and her belongings scattered round the sacred planace called "your studio"...I do dread being alone, I do need help and love and company but anything is better than life with you after you "fell in love". I have put quotation marks because I doubt if You can love anybody but your ambition. You don't love yourself, you don't love your art, you don't love human beings, you even don't love your family, they are a nuisance to you and they take of your time and your money... The only thing you cherish is your ambition to become a Great Painter, a Successful Artist and to have Freedom to get as many girls you can mange. And to get that you are ready to sacrifice your wife! I owe you one tremendous thing: you made me a painter and a good one, too. I will never forget about it. [...] You will make unhappy and woman who will love you or, if she does not love you, you will be unhappy with her. Not because you need somebody's love - you need to be worshipped and have somebody completely subserved to your needs and whims. A charwoman and a secretary can do the job I was doing for you, and as to the rest just occasional drifters would do it for you, and you will have your FREEDOM... ${ }^{82}$.

${ }^{77}$ AE/HK-Ż, list H. Korn do M. Żuławskiego, lata 60. XX w.

${ }^{78}$ AE/HK-Ż, list H. Korn do M. Żuławskiego, 22 stycznia 1961.

${ }^{79}$ AE/HK-Ż, list M. Żuławskiego do H. Korn, [b.d.].

${ }^{80}$ AE/HK-Ż, list M. Żuławskiego do H. Korn, 21 maja 1961.

${ }^{81}$ Zgromadzona w Archiwum Emigracji korespondencja Haliny Korn i Marka Żuławskiego zawiera wiele listów, pisanych w językach angielskim i francuskim.

${ }^{82}$ AE/HK-Ż, list H. Korn do M. Żuławskiego, 5 lipca 1959. 
Listy Żuławskich, pisane do siebie, nie pozostawiają wątpliwości: Marek był akuszerem narodzin Korn jako artystki w latach wojennych, ale i powodem jej upadku i załamania jako kobiety i żony. I w konsekwencji - jako artystki. Umieszczając ją w szpitalu psychiatrycznym „za karę”, gdzie „leczenie” wywoływało pożądane dla niego skutki ${ }^{83}$ Korn stawała się coraz bardziej nieobecna w jego życiu, obojętna na jego negatywne wobec niej zachowania i wycofana, aby w ostateczności zaprzestać okazywania jakichkolwiek emocji; odebrał jej to, co było jedyną radością jej życia — sztukę, bo, jak wiadomo z zachowanych dokumentów, Korn przestała tworzyć zupełnie.

Wielka miłość stała się z czasem tragedią Haliny Korn. Nieustannie walczyła o przetrwanie, najpierw podczas wojny, kiedy była we Francji zdana tylko na siebie, a potem w małżeństwie, trwała i była silna dzięki sztuce, w której - co najbardziej niezwykłe - widz nie odnajdzie cierpienia, którego doznała. W przedstawionym poniżej analizowanym fragmencie jej twórczości uwidaczniają się głównie tęsknoty i poetycki sposób patrzenia na życie. Sztuka Korn, na przekór temu, czego malarka doświadczała, jest pogodna, umożliwiała jej ucieczkę w pozytywny świat pełen kolorów i pozytywnych emocji. Na potwierdzenie powyższych twierdzeń można przytoczyć uwagę H. Segal, która napisała, że akt twórczy w swoim głębinowym wymiarze odnosi się do nieświadomej pamięci harmonijnego, wewnętrznego świata oraz do doświadczenia jego destrukcji; to znaczy, że u jego podstaw tkwi pozycja depresyjna ${ }^{84}$. Zdaniem uczonej, impuls artystyczny polega na próbie odzyskania i odtworzenia tego utraconego świata ${ }^{85}$. Korzystając $\mathrm{z}$ teorii Segal, można więc zauważyć, że artystka w trakcie swej pracy twórczej ponownie przepracowuje swoją pozycję depresyjną, nie tyko jednak odtwarza w swoim świecie wewnętrznym to, co koresponduje $\mathrm{z}$ jej wewnętrznym światem, ale też uzewnętrznia i powołuje do życia wszystko to, co jest wytworem jej świata wewnętrznego ${ }^{86}$.

Pomimo bogactwa tematów, jakie można zaobserwować, oglądając prace artystki, na pierwszy plan wybija się problematyka kobieca. Nie jest to jednak „,sztuka kobieca” w rozumieniu współczesnym, w którym istotą myślenia jest ideologia gender, gdyż w latach twórczości Korn o ideologii gender nie mogło być jeszcze mowy. Mówiąc o problematyce kobiecej w sztuce Haliny Korn, mam na myśli dzieła sztuki namalowane bądź wyrzeźbione przez artystkę, w których główną rolę odgrywa postać kobieca. W okresie życia H. Korn „kobiecość” była postrzegana i rozumiana zgoła inaczej niż współcześnie, mało tego - „kobiecość” na zachodzie Europy różniła się znacząco od „kobiecości” w krajach bloku wschodniego — w tym w ówczesnej Polsce Ludowej. Relację tę doskonale wizualizuje obraz Wojciecha Fangora Postaci ${ }^{87}$ z 1950 roku. Ma

${ }^{83}$ Żuławski wyznał: „muszę wyznać, bo to od lat nie daje mi spokoju, że kiedyś dawno moja modlitwa, żeby Pan Bóg zabrał Halinkę z tego świata została wysłuchana. Tak, modliłem się o śmierć swojej żony. [...] właśnie wtedy zrozumiałem, że to jedyne wyjście dla niej — i dla mnie", zob.: M. Żuławski, Studium do autoportretu, s. 427.

${ }^{84}$ Pozycja depresyjna - jest to konstelacja relacji z obiektem i lęków dotyczących dziecięcych doświadczeń ataków na ambiwalentnie kochaną matkę i utraty jej jako zewnętrznego i wewnętrznego obiektu. Doświadczenie to jest źródłem bólu, poczucia winy i utraty; zob.: H. Segal, Wprowadzenie do teorii Melanie Klein, Gdańsk 2005, s. 147.

${ }^{85}$ H. Segal, Marzenie senne, s. 133.

${ }^{86}$ Por.: tamże, s. 136.

${ }^{87}$ Wojciech Fangor, Postaci, 1950, olej na płótnie, $100 \times 125$ cm, Muzeum Sztuki w Łodzi. 
on niezwykle bogatą paletę znaczeń, ale w tym przypadku można potraktować go jako alegorię Europy Wschodniej i Zachodniej. W Postaciach kobieta - elegantka/kusicielka symbolizuje zachód Europy, a tym samym ,zepsuty” kapitalizm, natomiast para (kobieta i mężczyzna) robotników w roboczym ubraniu jest odzwierciedlaniem „ludu pracy” krajów komunistycznych. Korn, mająca znikomy i tylko pośredni kontakt z przeobrażeniami komunizmu w Polsce, postrzegała postać kobiecą ,po angielsku", obce jej były widoki pań w roboczych kombinezonach na traktorach, robotnice-włókniarki czy murarki, a bliskie i dobrze znane - dbające o swoją fizyczność, podkreślające swoje piękno, interesujące się modą, zaaferowane domowymi sprawami i dziećmi. Przestrzeń funkcjonowania kobiet była więc dość wąska, głównie dlatego, że w znakomitej większości pozostawały one zależne od swych mężów czy partnerów.

W swoich obrazach i rzeźbach artystka ukazała postać kobiecą w różnych rolach, zarówno matki, kochanki, jak i kobiety aktywnej zawodowo, zajętej sobą. Do prac o tematyce związanej z macierzyństwem zaliczyć można obraz Mother and Children with a Pram $^{88}$ oraz terakoty: Fighting Kids (1948) (il. 7), Portret dziecka (1949) (il. 8), Macierzyństwo (1950) (il. 10) i Matka i dziecko (il. 9). Prace, które pokazują kobietę w roli partnerki czy kochanki, to przede wszystkim obrazy: Kobieta i mężczyzna z piłka (1960-1964) (il. 3), W barze kawowym (1966) (il. 1), Miłość matżeńska (il. 4), Kochankowie (il. 2), natomiast obrazy podejmujące tylko tematykę kobiecą to: Kobieta leżaca na trawie (1960-1964) (il. 5), Kobieta myjąca wtosy (1960-1964) (il. 6) oraz Łaźnia kobieca ${ }^{89}$.

Wymienione dzieła to przykłady prac z bogatego dorobku artystki, znajdujących się w dostępnych polskich i obcych kolekcjach. Większość - W barze kawowym (il. 1), Kobieta myjaca włosy (il. 6), Kobieta leżaca na trawie (il. 5), Kochankowie (il. 2), Kobieta i mężczyzna z pitka (il. 3) — znajduje się w Muzeum Uniwersyteckim w Toruniu. Obraz Łaźnia kobieca jest częścią kolekcji Anthony’ego Petullo, który zbiera dzieła artystów amatorów i malarzy naiwnych. Naturalnie, oprócz wymienionych dzieł, w dorobku artystki znajduje się wiele innych obrazów, sytuujących kobietę w centrum zainteresowania, jednak wybór powyższych był uwarunkowany przede wszystkim różnorodnością przedstawionych ról kobiecych oraz dostępnością obrazów w Muzeum Uniwersyteckim w Toruniu.

Wspomniane prace malarskie, poza tematyką, mają wiele cech wspólnych. Analizując stronę techniczną, można zauważyć ich zbliżone wymiary. Są to obrazy raczej średniej wielkości, trzy - malowane farbą olejną na płycie, a pozostałe — również olejne, ale na płótnie. Miłość matżeńska (il. 4), W barze kawowym (il. 1), Mother and Children with a Pram, Kobieta i mężczyzna z piłka (il. 3) i Kochankowie (il. 2) to obrazy namalowane w formacie stojących prostokątów, natomiast Łaźnia kobieca, Kobieta leżaca na trawie (il. 5) i Kobieta myjąca włosy (il. 6) zostały namalowane w kadrach leżących prostokątów.

Cztery obrazy ( $W$ barze kawowym (il. 1), Łaźnia kobieca, Mother and Children with a Pram i Kochankowie, il. 2) różnią się od pozostałych. Wymienione prace są niezwykle barwne i zróżnicowane kolorystycznie. Wydaje się, że do ich namalowania

${ }^{88}$ 8. Halina Korn-Żuławska, Mother and Children with a Pram, b.r., olej na płótnie, $42,5 \times 38$ $\mathrm{cm}$, miejsce przechowywania nieznane; zob.: ARCADJA. Auctions Results, http://www.arcadja.com/auctions/en/korn_halina/artist/117425/ (dostęp: grudzień 2016).

${ }^{89}$ 6. Halina Korn-Żuławska, Bathhouse / Łaźnia kobieca, b.r., olej na płycie pilśniowej, 38,1 $\times 61 \mathrm{~cm}$, miejsce przechowywania: The Anthony Petullo Collection of Self-Taught and Outsider Art; zob.: M. Andera, The Anthony Petullo Collection of Self-Taught and Outsider Art, [Urbana 2001], s. 87. 
malarka użyła niemal całej palety barw. Pozostałe dzieła (Kobieta i mężczyzna z pitka (il. 3), Kobieta leżaca na trawie (il. 5), Kobieta myjaca włosy, il. 6) to dzieła o dość wąskiej gamie barwnej, cechuje je ciemna i zgaszona kolorystyka ${ }^{90}$. Na każdym z czterech wyżej przedstawionych obrazów ukazane zostały kobiety w różnych relacjach (i sytuacjach) z mężczyznami.

Na obrazie $W$ barze kawowym (il. 1) jawi się scena flirtu, rozgrywającego się w romantycznej, kawiarnianej przestrzeni. Obraz przedstawia siedzące za stolikiem, zwrócone ku sobie postaci - mężczyznę i kobietę. Para zajmuje połowę kadru. Kompozycyjnie - postaci tworzą kształt litery „V”. Mężczyzna obejmuje lewym ramieniem kobietę, jest w nią wpatrzony i całkowicie na niej skupiony. Kobieta jest lekko odchylona w tył, jej lewa ręka, w której trzyma papierosa, spoczywa na stoliku obok szklanki z jakimś napojem. Obydwoje ubrani są elegancko - mężczyzna w białą koszulę z kołnierzykiem oraz marynarkę, a kobieta w bluzkę lub sukienkę z głębokim dekoltem w tak zwany serek. Na drugiej połowie przedstawienia widnieje sporych rozmiarów wazon z bukietem kwiatów. Kompozycja kwiatowa zdaje się dominować swoją wielkością nad resztą figur. Para została namalowana w półpostaci, ich sylwetki są mocno wydłużone. Tak ręce obydwojga, jak i szyja kobiety są wyraźnie nieproporcjonalnie długie w stosunku do wymiarów sylwetek. Postaci są uproszczone i odindywidualizowane. Sylwetki kobiety i mężczyzny zostały skomponowane z płynnych, długich linii i wyróżnia je z reszty obrazu ich rysunkowy charakter. Artystka użyła czystych, głębokich barw do namalowania postaci, które zdają się płaskie. Wazon z bukietem kwiatów, w odróżnieniu od sposobu kształtowania postaci, jest bardzo malarski, charakteryzuje się różnorodnością form i kształtów kwiatów. Postrzępione i delikatne kształty jednych kontrastują ze zwartą i mięsistą formą innych. Kwiaty, dodając uroku całej scenie, wprowadzają nastrój beztroski.

Na obrazie Kochankowie (il. 2) w stosunkowo dosadny sposób ukazany został akt seksualny. Dzieło przedstawia nagiego mężczyznę i kobietę, złączonych w miłosnym uścisku. Ujęcie kadru wskazuje, że kochankowie znajdują się w łóżku, jednak w bliżej nieokreślonej przestrzeni. Postacie zajmują niemal cały kadr obrazu, ich sylwetki skierowane są ku sobie, zostały namalowane w pozycji półleżącej i znajdują się na diagonali płótna. Mężczyzna, skierowany przodem do widza, obejmuje kobietę prawą dłonią, zaś drugą ma wyprostowaną, widoczny jest fragment jego narządów płciowych. Natomiast kobieta, która podpiera się na lewym łokciu i obejmuje partnera udami na wysokości pasa, została ukazana tyłem. Jej prawa ręka spoczywa na lewym ramieniu mężczyzny. Sylwetka kobiety została ułożona tak, że zasłania po części ciało kochanka, dzięki czemu widać tylko jego lewą część. Mężczyzna jest raczej szczupłej budowy widać zarys żeber, jego ciało ma barwę szarawą, co kontrastuje z jasnym, świetlistym kolorem skóry jego zmysłowej partnerki. Łóżko, na którym znajdują się postacie, ukazane jest fragmentarycznie, widoczne są jedynie skrawki pomarańczowej pościeli lub narzuty, co zlewa się z czerwonymi ścianami wnętrza. Podobnie jak na wcześniej opisywanym obrazie, ciała są wydłużone, jednak w tym przypadku widać pewniejszą rękę w ich kształtowaniu. Na uwagę zasługuje również fakt, że malarka odważnie zestawiła ze sobą dwa podobne do siebie kolory — czerwień i oranż, dzięki czemu tło przedstawienia nie rozprasza widza, powodując tym samym skupienie całej uwagi na postaciach. Obraz sprawia wrażenie niezmiernie surowego i skromnego, jednak jego kolory-

\footnotetext{
${ }^{90} \mathrm{Na}$ marginesie powyższych opisów pozostaje obraz Miłość malżeńska. Nie został „,sklasyfikowany”, ponieważ jedyna dostępna reprodukcja jest czarno-biała i trudno w takim przypadku snuć rozważania o kolorystyce czy fakturze.
} 
styka i ułożenie form powodują, że nastrój przedstawionego tematu jest niezwykle intymny i dosadny w odbiorze — widz nie ma wątpliwości, że na obrazie został ukazany akt seksualny.

Miłość małżeńska (il. 4) to przedstawienie niezwykle intymnej sceny rozmowy, rozgrywającej się pomiędzy żoną a mężem w małżeńskiej sypialni. Mężczyzna leży na łóżku, a przy nim siedzi kobieta. Postać kobieca znajduje się na osi pionowej. Kobieta jest naga, siedzi na krawędzi łóżka, zwrócona bokiem do widza. Natomiast mężczyzna skierowany jest w stronę swojej partnerki, plecami opiera się o sporej wielkości poduszkę, podpiera się na prawym łokciu, przyjmując pozę półleżącą, obejmuje kobietę lewą ręką. Mężczyzna ubrany jest w strój domowy, prawdopodobnie jest to pidżama $\mathrm{z}$ głębokim rozcięciem na klatce piersiowej. Jego partnerka jest młodą kobietą o smukłej, a zarazem kobiecej sylwetce i obfitym biuście. Pomimo czarno-białej reprodukcji wydaje się, że w pomieszczeniu panuje półmrok, dzięki któremu wyczuwa się intymną atmosferę oraz pewną dozę tajemniczości.

O ile w opisanych powyżej obrazach relacje kobieta-mężczyzna są jasne, o tyle zagadkowy wydaje się obraz Kobieta i mężczyzna z piłką (il. 3), ukazujący dwie nagie postacie $\mathrm{w}$ nieokreślonej przestrzeni, $\mathrm{z}$ tajemniczym przedmiotem $\mathrm{w}$ rękach mężczyzny. Trudno w tym przypadku odgadnąć, jakie relacje łączą obojga bohaterów. Ich wspólnym mianownikiem jest nagość, co pozwala sądzić, że ukazana para jest ze sobą w bliskich relacjach - być może są kochankami. Jednak przy próbie analizy tego przedstawienia nasuwają się pytania: czy jest to scena nawiązująca do biblijnych pierwszych ludzi - Adama i Ewy? Czy jest to rodzaj zabawy, w której istotną rolę odgrywa tajemniczy, żółty przedmiot? Element ten przywołuje na myśl obraz Marka Żuławskiego pod tytułem: Ludzie nad morzem ${ }^{91}$, gdzie pojawił się podobny przedmiot — żółta piłka, którą podrzuca dziewczynka. Jest jeszcze jeden aspekt w obrazie Kobieta $i$ mężczyzna z pitka (il. 3), przypominający manierę Żuławskiego - mianowicie charakterystyczny profil mężczyzny, którego czoło znajduje się w jednej linii z nosem, ponieważ nie zostało zaznaczone zagłębienie, oddzielające nos od czoła.

W każdym z wymienionych obrazów kobiety pozostają raczej bierne. To mężczyźni odgrywają kluczowe role, a ich partnerki są jakby odbiorcami męskiej aktywności. Kobiety, wpatrzone w swoich partnerów, skupiają na nich całą swoją uwagę. W każdym dziele, z wyjątkiem obrazu Kobieta i mężczyzna z piłka (il. 3), malarka stworzyła pomiędzy postaciami niezwykle romantyczną, pełną napięcia atmosferę. Obrazy te odzwierciedlają naturalną kolej rzeczy, kiedy to dochodzi do spotkania dwóch różnych pierwiastków: kobiecego i męskiego, moment, w którym następuje proces poznawania, zakochania, seksualnej fascynacji, partnerstwa, zabawy. W pracach tych Korn przedstawia widzowi swoją wizję narzeczeństwa, partnerstwa, małżeństwa czy przyjaźni. W centrum umieszcza kobietę jako odbiorcę, czy też przyczynę męskiej adoracji i aktywności.

Obrazy te (z wyjątkiem obrazu $W$ barze kawowym, il. 1) są najpewniej imaginacjami artystki i nie zostały namalowane na podstawie obserwacji modeli podczas sytuacji intymnych. Można domniemać, że Korn przelała na płótno swoje pragnienia, tęsknoty i fantazje. Według H. Segal artysta odczuwa potrzebę odtworzenia tego, czego doświadcza w głębiach swego wewnętrznego świata ${ }^{92}$. Jest to uderzające, kiedy weźmiemy pod uwagę życie małżeńskie Haliny Korn i Marka Żuławskiego, które de facto

\footnotetext{
${ }^{91}$ Ludzie nad morzem, 1957, olej na płótnie, $208 \times 290 \mathrm{~cm}$, Muzeum Uniwersyteckim w Toruniu; reprodukcja barwna w: M. Żuławski, Studium do autoportretu, wyklejka.

${ }^{92}$ H. Segal, Marzenie senne, s. 122.
} 
znamy z dwóch stron, dzięki przytoczonej wcześniej, licznej korespondencji oraz napisanej przez Żuławskiego autobiografii, w której przedstawił swój punkt widzenia na sprawy małżeńskie i „opowiedział historię” związku z Korn. Perspektywę malarki znamy z listów do przyjaciół oraz z zachowanej domowej korespondencji obydwojga artystów, z której wynika, jak burzliwy związek tworzyli. Warto dodać także, że obrazy te zostały namalowane w najtrudniejszym chyba dla artystki czasie, kiedy zabiegała o separację, a jej niechęć do męża, spowodowana odrzuceniem przez Marka i brakiem miłości z jego strony, była największa. Ma to znaczenie w analizie prac. Gdy posłużymy się psychoanalizą, uzyskamy potwierdzenie, że tworzenie świata wewnętrznego jest zarazem nieświadomym odtwarzaniem świata utraconego ${ }^{93}$. Zdaniem Segal, nieświadome fantazje tkwią u podłoża i zabarwiają wszystkie formy ludzkiej aktywności, niezależnie od tego, jak dalece są one realistyczne ${ }^{94}$. Niektóre jednak zjawiska i formy aktywności bardziej bezpośrednio zmierzają do wyrażenia i symbolizacji nieświadomych fantazji. Należą do nich nie tylko nocne marzenia senne, ale również marzenia na jawie, zabawy i sztuka ${ }^{95}$.

Korn, jako zaprzeczenie kobiety biernej, była silna, wykształcona i zaradna, znamionowała ją niezwykle wyrazista i barwna osobowość. Dzięki swojej pracy i determinacji rozwinęła się jako artystka i dzięki (w większości) swoim działaniom wystawiała prace $\mathrm{w}$ tak wielu galeriach sztuki. W listach do męża, pisanych z podróży np. $\mathrm{z}$ Paryża, Korn zwierzała się ze swoich działań na rzecz propagowania własnej twórczości nad Sekwaną. W późniejszych latach za cel obrała zorganizowanie wystawy swoich prac w Nowym Jorku.

Silna, niedająca się zdominować, poniekąd niezależna (poza sprawami finansowymi), Korn malowała kobietę delikatną, subtelną, oddaną mężczyźnie, podatną na jego zaloty, ale przede wszystkim kobietę raczej bierną i uległą, taką, która idealnie wpasowuje się w przynależną jej rolę społeczną. Pokazuje to sposób myślenia malarki o roli kobiety $\mathrm{w}$ związku i $\mathrm{w}$ relacji $\mathrm{z}$ mężczyzną. Jest to jedna $\mathrm{z}$ najtrwalszych klisz społecznych, według której mężczyzna jest aktywnym „składnikiem” związku, a w globalnym wymiarze - w życiu społecznym, to mężczyźni są postrzegani jako twórczy, sprawczy i pracujący, a kobiety jako bierne, uległe, często nieporadne i zdane na mężczyznę ${ }^{96}$.

Pomimo dwóch różnych wizji kobiecości, można znaleźć wspólną płaszczyznę w malowaniu kobiet przez Żuławskiego i Korn. W przedstawionych powyżej obrazach kobieta zdaje się obiektem seksualnym, przedmiotem męskiego upodobania i pożądania. Jednak Korn uczyniła to niezwykle subtelnie, jej prace nie budzą negatywnych emocji. Obrazy eksponują kobiecą delikatność i wrażliwość oraz ukazują kobiecą wizję świata. Kobiety na obrazach Żuławskiego są uprzedmiotowione i wręcz niepokoją widza swoim erotyzmem, artysta często sprowadza postać kobiecą do cech charakterystycznych dla damskiej sylwetki — maluje same korpusy, pozbawione głów. Kobieta u Żuławskiego jest biernym obiektem pożądania.

Prawdopodobnie zupełnie nieświadomie Korn utożsamiła kobietę z obiektem seksualnym, niemniej pokazuje to, jak mocno zakorzeniona w świadomości, jak również podświadomości (bo należy brać pod uwagę, że w ówczesnym czasie dyskurs, dotyczący sztuki feministycznej, dopiero „raczkował” i dotyczył głównie równouprawnie-

\footnotetext{
93 Tamże, s. 124.

94 Tamże, s. 143.

95 Tamże, s. 143.

${ }^{96}$ I. Kowalczyk, Ciało i władza: polska sztuka krytyczna lat 90., Warszawa 2002.
} 
nia kobiet i mężczyzn w dziedzinie sztuki) była rola kobiety jako obiektu seksualnego i przedmiotu męskich pragnień.

Kolejną grupą prac są obrazy o tematyce stricte kobiecej. Malarka ukazuje postać kobiecą podczas wykonywania różnych codziennych czynności. Każda z zamieszczonych poniżej reprodukcji prezentuje kobietę w trakcie zajęć, będących domeną „płci pięknej”. W pracach Kobieta myjąca włosy (il. 6) i Laźnia kobieca kobiety zajęte są pielęgnacją własnego ciała, natomiast Kobieta leżaca na trawie (il. 5) zaabsorbowana jest czytaniem książki i odpoczywaniem na łonie przyrody.

Obraz Łaźnia kobieca, namalowany dzięki obserwacji kobiet w saunie, pokazuje, w jaki sposób troszczą się one czy też dbają o własne ciało, jakim zabiegom je poddają, by wyglądać atrakcyjnie i czuć się dobrze. Praca ta zdaje się niemal fotograficznym uchwyceniem zachowań pięciu kobiet, pokazuje różnorodność zabiegów i bogactwo pielęgnacyjnych „rytuałów”. Obraz ukazuje pięć kobiet, przebywających w łaźni i sprawujących toaletę. Kompozycja jest zróżnicowana, przyciąga uwagę bogactwem póz, elementów oraz ciekawą kolorystyką. Każda z kobiet znajduje się w oddzielnej kabinie. Szatnie są otwarte na widza, dzięki czemu widać, co robią znajdujące się w nich postacie. W pierwszym pomieszczeniu na ławeczce, przodem do widza, siedzi naga kobieta. Postać ma założoną nogę na nogę, jest lekko zgarbiona, a jej ręce splatają się na krzyżujących się kolanach. Na wieszakach na ściance wiszą ubrania i ręcznik.

Kobieta stojąca w drugim boksie została namalowana w trakcie ubierania się bądź rozbierania. Jej postać niemal do połowy zasłaniają przymknięte drzwi kabiny. Kobieta stoi bokiem do widza, jednak górna część jej tułowia odwrócona jest lekko w stronę ściany. Widać tył jej głowy oraz ledwo dostrzegalny zarys profilu. Ma uniesione, wyprostowane ręce, przez które wkłada lub zdejmuje bluzkę.

W kolejnej — środkowej — szatni znajduje się kobieta, pochylająca się nad torebką, w której czegoś szuka. Postać jest zwrócona przodem w kierunku widza. Okazała sylwetka kobiety jest widoczna niemal w całości. W czwartej przebieralni stoi kobieta, która wyciera ręcznikiem włosy, jest odwrócona tyłem do widza. W ostatniej szatni, której drzwiczki są zamknięte, stoi kobieta, zwrócona bokiem do widza. Postać widoczna jest tylko do linii biustu, gdyż resztę sylwetki zasłaniają drzwi.

Kolorystyka obrazu jest skomponowana na zasadzie kontrastów. Ciemna barwa otoczenia kontrastuje z nagimi ciałami kobiet. Poprzez zróżnicowanie póz i wykonywanych czynności, obraz sprawia wrażenie dynamicznego i złożonego kompozycyjnie.

Kobieta leżąca na trawie ${ }^{97}$ (il. 5) to praca, wydawać by się mogło, dość ekscentryczna. Ukazuje kobietę mało atrakcyjną, o dziwnej posturze, której ułożenie ciała, najprościej rzecz ujmując, przypomina pozę sansowinowską. Z kolorystyki obrazu można wnioskować, że na leśnej polanie panuje już półmrok, w którym, ku zdziwieniu widza, kobieta czyta książkę. Z tego właśnie powodu przedstawienie to zdaje się odrealnione, niemal baśniowe. Otoczenie, w którym znajduje się postać, nie jest przyjazne, robi raczej wrażenie dzikiego, nieprzewidywalnego, mrocznego lasu, niezbyt bezpiecznego dla nagiej, bezbronnej kobiety. Nie ma wątpliwości, że postać odpoczywa, czytając książkę, jakby to, w jakim miejscu się znajduje, nie robiło na niej wrażenia. Dzika przyroda jest dla niej naturalnym miejscem egzystowania. Naga kobieta $\mathrm{z}$ obfitymi piersiami, wypoczywająca na łonie natury, przypomina archetyp kobiety-matki.

${ }^{97}$ Praca ta ma swój odpowiednik w postaci obrazu o przypuszczalnym tytule Mężczyzna leżacy na trawie [b.d.]. Wydaje się, że obydwa dzieła stanowią rodzaj dyptyku. Bohaterem tego dzieła jest postać nagiego mężczyzny, leżącego na trawie i czytającego książkę w podobnie odrealnionej, niemalże baśniowej przestrzeni tajemniczego, mrocznego lasu. 
Kobieta myjąca włosy (il. 6) to jeden z najbardziej zagadkowych obrazów Haliny Korn. Główną bohaterką jest kobieta podczas sprawowania toalety. Jest to obraz niezwykle ciekawy pod względem kompozycyjnym, sprawia wrażenie surrealnego. Został niejako podzielony na dwie części, jakby opowiadał niezależne, toczące się obok siebie historie. Akcja toczy się w niedookreślonej, nostalgicznej oraz tajemniczej przestrzeni, która podzielona została na dwie strefy - strefę wnętrza i zewnętrza, w których granica jest okno, sprawiające wrażenie krat, stanowiące jednocześnie kadr obrazu. Lewa część obrazu przedstawia to, co odbywa się na zewnątrz, natomiast prawa strona ukazuje element wnętrza, czyli łóżko. Głównym tematem obrazu jest naga, młoda kobieta siedząca na łóżku z wplecionymi w rozpuszczone włosy dłońmi. Należy dodać, że łóżko stoi na tle wielkiego okna. Na zewnątrz, po lewej stronie kadru, znajduje się zwrócony w prawą stronę mężczyzna, spacerujący z niewielkim psem. Przestrzeń, która otacza przechodnia, jest niezwykle zagadkowa. Jedną trzecią szerokości obrazu zajmuje pas nieba, natomiast pozostałą część stanowi tło, ciągnące się aż po horyzont. Naga kobieta siedzi na łóżku przodem do widza, w lekkim rozkroku, dzięki czemu widoczne jest jej łono. Uda postaci widoczne są tyko do połowy, ponieważ pozostałą część nóg przysłania oparcie łóżka, które zajmuje niemal połowę kadru i namalowane zostało w dość niefortunnym skrócie perspektywicznym. Postać charakteryzuje się szczupłą budową ciała. Uwagę zwracają ogromne, kształtne piersi z wyraźnie zaznaczonymi sutkami. Kobieta ma uniesione ręce, a dłonie jej wplecione są w czarne, opadające na ramiona włosy. Twarz postaci wydaje się ledwie zarysowana. Kolorystyka obrazu jest stonowana. Na tle ciepłych, zgaszonych barw wyróżnia się jasne, niemalże białe ciało kobiety, blada twarz mężczyzny oraz szaro-białe ramy okienne, przypominające kraty. Brązowo-żółte tło kontrastuje $\mathrm{z}$ ciężkim, mętnym błękitem nieba. Barwy, które zastosowała artystka, są zabrudzone, sprawiają wrażenie mieszanych bezpośrednio na płótnie. W obrazie tym nie ma faktycznej granicy pomiędzy intymnym wnętrzem a światem zewnętrznym. Zdziwienie widza może budzić fakt, że tytułowa kobieta, myjąca włosy, nie znajduje się wcale w łazience, a siedzi na łóżku, które prawdopodobnie znajduje się w sypialni. Na pierwszy rzut oka widać, że łóżko to znajduje się w jakiejś nieokreślonej przestrzeni — jakby stało na zewnątrz, dopiero po chwili dostrzegalne są ramy wielkiego okna, umożliwiającego obserwację z zewnątrz tego, co dzieje się w środku. Sytuacja przedstawiona na obrazie jest niejasna, gdyż trudno jest zinterpretować, czy przedstawiona naga, młoda i atrakcyjna kobieta obnaża się przed światem zewnętrznym - w tym przypadku przed spacerującym z psem mężczyzną? Dlaczego ukazane wnętrze, w którym odbywa się intymna scena, wygląda niemalże jak witryna sklepowa, w której znajduje się wystawa?

Każda z prezentowanych przez artystkę kobiet prezentuje zupełnie inny typ kobiecości. Korn pokazuje kusicielkę — kobietę młodą, atrakcyjną, bezwstydną, zajętą sobą; kobietę - odpoczywającą, żyjącą w zgodzie z naturą i będącą jej integralną częścią; kobietę - dbającą o dobre samopoczucie i swój wizerunek. Dzięki tym obrazom dostrzec można niemal wszystkie „etapy” czy fazy rozwoju, poprzez które przechodzi kobieta, stając się wreszcie pogodzoną ze sobą, świadomą swojej siły i natury jednostką.

$\mathrm{W}$ pracach artystki nieustannie przewijała się tematyka macierzyństwa jako próby pogodzenia się lub uporania z niespełnioną rolą bycia matką. Z notatek i listów, pozostawionych przez Halinę Korn, wynika, że posiadanie dziecka było jej największym marzeniem i tęsknotą, spowodowaną samotnością i brakiem szczęścia małżeńskiego. W Studium do autoportretu Marek Żuławski wyznał, że nie był gotowy, aby mieć dzie- 
ci. Twierdził, że posiadanie dziecka w okresie młodości to duża lekkomyślność, na którą on wówczas nie potrafił sobie pozwolić ${ }^{98}$.

Sposobem na pogodzenie się z zaistniałą sytuacją stało się dla artystki tworzenie pełnych uczucia i ciepła obrazów i figurek matek oraz dzieci. Omawiając problem macierzyństwa w twórczości Korn, ważne miejsce zajmuje obraz Mother and Children with a Pram. Jest to dzieło zadziwiająco żywe pod względem kolorystycznym i figuralnym. Obraz ten wzbudza niezwykle pozytywne uczucia. Jest przesycony jasnymi, ciepłymi barwami i pomimo wielu tak zwanych niedoskonałości technicznych, wzbudza zaciekawienie i pokazuje radość bycia matką, obcowania z dziećmi i całe piękno macierzyństwa. Ciekawość, a jednocześnie podziw może wzbudzać ilość dzieci, przedstawiona na obrazie - kobieta ma pod swoją opieką aż pięcioro małych dzieci i troje niemowląt. Być może kobieta, przedstawiona na obrazie, wcale nie jest matką, a piastunką gromadki dzieci? Korn pokazuje tutaj kobietę jako jednostkę świadomie i całkowicie poświęcającą się z radością roli matki czy dziecięcej opiekunki. Na podstawie obrazu można stwierdzić, że jest to rola totalna, całkowicie wypełniająca życie bohaterki, gdyż przy przedstawionej liczbie dzieci ciężko wyobrazić sobie, że kobieta mogłaby angażować się $\mathrm{w}$ inne zadania, niezwiązane z macierzyństwem. Według wyobrażenia Haliny Korn, rola jej bohaterki jest bardzo przyjemna, nacechowana głównie pozytywnymi i ciepłymi uczuciami czy emocjami, można powiedzieć, że wręcz sielankowa i bezproblemowa. Analizując ten obraz, musimy odpowiedzieć na pytanie: czy artystka namalowała go, bo została zainspirowana faktyczną obserwacją podobnej sytuacji na ulicy, czy też jest to wytwór jej wyobraźni? Wydaje się, że pytanie to odnosić by się mogło nie tylko do tego konkretnego obrazu, ale do całej twórczości Haliny Korn, o czym wspominałam wcześniej. Sama artystka wyznała, że najpierw obserwuje, a potem rysuje z pamięci, zapisuje tematy $w$ obawie, by ich nie zapomnieć ${ }^{99}$. Można więc przypuszczać, że każde dzieło autorstwa Korn jest po części namalowane z natury i jednocześnie wzbogacone o elementy wzięte $\mathrm{z}$ wyobraźni malarki.

Niewątpliwy talent i niezwykłe poczucie formy artystki ujawniły się wraz z kreacją niewielkich figurek z terakoty. Fighting Kids (il. 7), Portret dziecka (il. 8), Macierzyństwo (il. 10) i Matka i dziecko (il. 9) to kilkunastocentymetrowe, wyrzeźbione w glinie formy, przedstawiające dzieci oraz kobiety z dziećmi. Cechą wspólną wymienionych rzeźb jest ich zbliżona wizualnie forma i faktura. Rzeźby te charakteryzują się zwartą bryłą i mięsistą strukturą. Uwagę przykuwa ich prostota, uzyskana dzięki nadaniu rzeźbom zdecydowanie obłych kształtów oraz dość ogólnemu traktowaniu przez artystkę poszczególnych części ciała. Przedstawione rzeźby wydają się szczególnie interesujące w kontekście tematyki macierzyństwa, o której była już mowa przy okazji analizy obrazu Mother and Children with a Pram. Szczególną pozycję i wartość w dorobku artystycznym Korn prezentują niewielkie terakoty, przedstawiające dzieci. Z jednej strony rzeźby te wzbudzają bardzo pozytywne i ciepłe uczucia, bo dzieci, rzeźbione rękoma Haliny Korn, są malutkie, pucułowate, zaokrąglone i beztroskie, a z drugiej strony emanuje z nich surowość, jakaś trudna do wyrażenia dzikość i niepokój. Być może wrażenia te są spowodowane $\mathrm{w}$ dużej mierze przez materiał, $\mathrm{w}$ jakim prace zostały wykonane, oraz przez technikę wykonania, czyli kształtowanie palcami i nieprofesjonalnymi narzędziami rzeźbiarskimi. Brak wyszlifowania czy wygładzenia powierzchni przyczynił się do uzyskania wrażenia surowości rzeźb.

\footnotetext{
${ }^{98}$ Marek Żuławski został ojcem w wieku 67 lat, kiedy był w związku małżeńskim ze swoją trzecią żoną, Marią (Marylą) Żuławską.

${ }^{99}$ F. Topolski, M. Żuławski, Halinka, s. 5.
} 
Zupełnie inne odczucia, $\mathrm{w}$ porównaniu $\mathrm{z}$ obrazem przedstawiającym matkę z dziećmi, może wzbudzać terakota: Macierzyństwo (il. 10). Rzeźba przedstawia matkę podczas karmienia dwójki niemowląt. O ile dzieci wydają się bardzo żywe i ruchliwe, o tyle postać kobiety nie emanuje już pięknem i euforią, ale wydaje się przytłoczona, zmęczona i wręcz utrudzona swoją rolą.

Matka-opiekunka z obrazu jest kobietą zadbaną, dobrze ubraną, szczupłą i emanującą kobiecością, natomiast matka, wyrzeźbiona z terakoty, to jej totalne zaprzeczenie - zaniedbana, gruba, swoje ciało całkowicie poświęciła i podporządkowała dziecięcym wymaganiom. Jej niepokojący wyraz twarzy oddaje utrudzenie, zmaganie się z trudami codzienności i macierzyńskich obowiązków. Pod względem formalnym rzeźba ta nasuwa skojarzenia z prehistorycznymi figurkami Wenus, będącej symbolem Ziemi, płodności i urodzaju, której głównym zadaniem było wydawanie na świat potomstwa i zapewnianie ciągłości ludzkiej egzystencji.

Interesującym przedstawieniem kobiety — matki jest rzeźba Matka i dziecko (il. 9). W kontekście tego przedstawienia niezwykle intrygujący jest wyraz twarzy bohaterki. Zagadkowy dla widza, pozwala jedynie snuć przypuszczenia. Mina kobiety jest niejednoznaczna. $Z$ jednej strony można sądzić, że kobieta jest wystraszona, ponieważ ma szeroko otwarte oczy, wzrok utkwiony w jakimś punkcie przed nią oraz rozwarte usta, ponadto tuli do swojej piersi niemowlę, jakby chciała je ochronić. W przedstawieniu tym Korn ukazuje kobietę jako opiekunkę, piastunkę i dającą poczucie bezpieczeństwa i ciepła istotę.

Halina Korn była artystką niezwykle płodną i choć jej przygoda z malarstwem i rzeźbą rozpoczęla się stosunkowo późno, to dorobek artystyczny jest niezwykle bogaty. Artystka podejmowała każdą tematykę, którą tylko potrafiła namalować czy wyrzeźbić. Przedmiotem niniejszej publikacji była tematyka kobieca, stanowiąca zaledwie fragment twórczości artystki. Jednak wydaje się, że omówiona powyżej część dorobku malarki zdaje się najbardziej spójna i prezentuje wysoki poziom artystyczny, ponadto jest kompilacją pragnień i niespełnionych marzeń Korn, natomiast pozostała - to wynik obserwacji toczącego się wokół niej życia.

\section{LITERATURA}

Archiwum Emigracji w Toruniu, Archiwum Haliny Korn-Żuławskiej;

Archiwum Emigracji w Toruniu, Archiwum Marka Żuławskiego.

D. Buckman, The Dictionary of Artists in Britain since 1945, Bristol 1998;

S. Davidson, The Psychosocial Aspects of Holocaust Trauma in the Life Cycle of Survivor Refugees and Their Families, [w:] R. Baker, L. Kirkley, The Psychosocial problems of refugees, London 1983;

A. Drwęska, Akty i fakty, Tydzień Polski $1974 \mathrm{nr} 22$;

—, O prymitywach i wystawie Haliny Korn, Wiadomości 1953 nr 44 (396);

-, Po londyńskim sezonie wystaw, Orzeł Biały $1950 \mathrm{nr} 41$;

—, Pótroczny bilans malarski, Orzeł Biały $1951 \mathrm{nr} 38$;

-, Wystawa międzynarodowa kobiet-malarek, Dziennik Polski i Dziennik Żołnierza 1955;

—, Wystawy zimowego kwartału, Tydzień Polski 1977 nr 16;

M. Goff, Marek Zulawski and Halina Korn, Studio 1956 wol. 152;

S. Goodsir, A „Primitive” at the Traverse, The Scotsman 25.09.1964;

Halina Korn, „Sztuka polska na świecie”, oprac. J. Krasnodębska, http://www.muzeum.umk.pl/ sztuka_polska/halina-korn (dostęp: maj 2016);

H. Heinsdorf, Żarliwość Haliny Korn, Tydzień Polski 1964 nr 46; 
A. Jackowski, Sztuka zwana naiwna. Zarys encyklopedyczny twórczości w Polsce, Warszawa 1995;

Jewish Artists. The Ben Uri Collection. Paintings, Drawings, Prints and Sculpture, ed. by W. Schwab, J. Weiner, London 1994;

H. Korn-Żuławska, Wakacje kończa się we wrześniu, Warszawa 1983;

I. Kowalczyk, Ciało i władza: polska sztuka krytyczna lat 90., Warszawa 2002;

J. Krasnodębska, ,Angielka w Paryżu”. Listy Haliny Korn-Żuławskiej do męża (maj-czerwiec 1950), Archiwum Emigracji. Studia - Szkice — Dokumenty 2012 z. 1-2 (16-17);

H. Segal, Marzenie senne, wyobraźnia i sztuka, Kraków 2003;

H. Segal, Wprowadzenie do teorii Melanie Klein, Gdańsk 2005;

J. W. Sienkiewicz, Sztuka oswajania świata. O obecnościach twórczości plastycznej niepelnosprawnych umysłowo $w$ polskiej sztuce wspótczesnej, [w:] Osoby niepetnosprawne $w$ życiu społeczeństwa i kościoła, red. A. Bartoszek, D. Sitko, t. 1, Katowice-Ruda Śląska 2003;

M. A. Supruniuk, Kadisz za sztetl, [w:] Życie sztetla w sztuce Żydów polskich na świecie w XX w. Prace ze zbiorów Biblioteki Uniwersyteckiej, Archiwum Emigracji oraz Towarzystwa Przyjaciót Archiwum Emigracji, [praca zbiorowa], Torun 2016;

Sztuka polska w Wielkiej Brytanii 1940-2000: antologia, oprac. M. A. Supruniuk, Torun 2006;

P. Szubert, Picasso i Kubiści, [w:] Sztuka Świata, red. W. Włodarczyk, t. 9, Warszawa 1996;

F. Topolski, M. Żuławski, Halinka, Wiadomości 1979 nr 3 (1712);

Z. Turkiewicz, Wystawy londyńskie, Kultura 1966 nr 1-2 (219-220);

P. Vann, Face to Face. British Self-Portraits in the Twientieth Century, London 2004;

Wystawa Kobiety Polskiej, Dziennik Polski 1942 nr 558;

[Stefania Zahorska] St. Z., Halina Korn w „, Galery One”, Dziennik Polski i Dziennik Żołnierza $1960 \mathrm{nr}$ 46;

M. Żuławski, Studium do autoportretu, Toruń 2009.

\section{BETWEEN FEAR AND ART. WOMEN IN THE WORKS OF HALINA KORN- -ŻULAWSKA}

The article is a reflection on the ambiguous and diverse art by Halina Korn. Still underrated, the painter, sculptor and writer worked in the shadow of her prominent husband Marek Żuławski as one of the so called "naive artists." Is that valid? The critics cited in this writing answer this question. "Between fear and art" is also an attempt to abolish the theory that Korn was suffering from depression, through which her works may me interpreted. It was not the disorder, but the extraordinarily strong and ambiguous influence of her husband which determined the form and content of her artistic message - a relationship between kindred spirits, marked by loneliness, became the reason of both Korn's birth and death as an artist and a woman. Femininity, so important and constantly tested so severely in her non-artistic life thus became the dominating element of her output. Correlated - be it painted or sculpted - the various views of femininity are a tale of the artist herself: a liberated, attractive temptress, a mother-Korn was never to play that role - reading the clues, sometimes obvious, sometimes subtle, we enter into a space where it is hard to separate the artistic from real life.

KEYWORDS: depression; woman; marriage; loneliness; naive art; war trauma. 


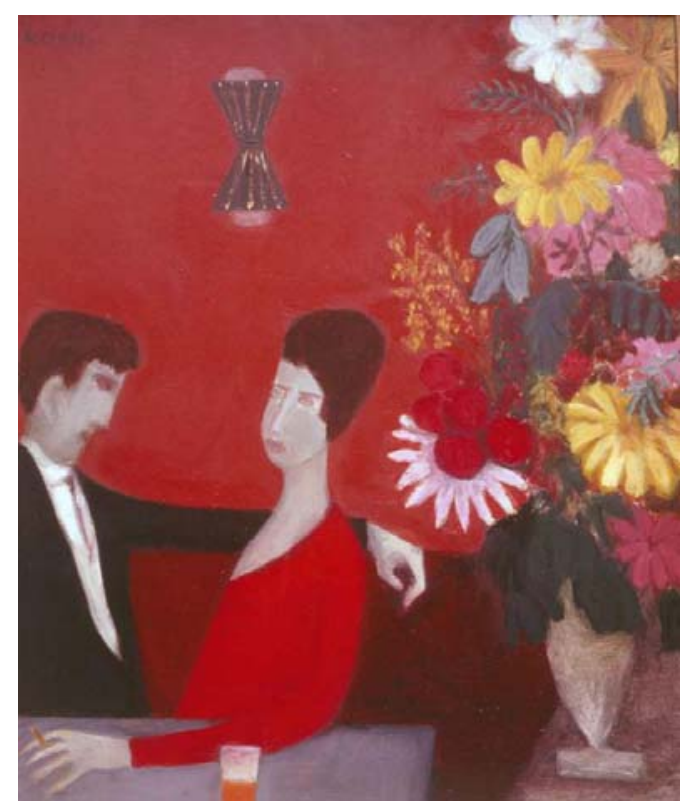

1. W barze kawowym, 1963

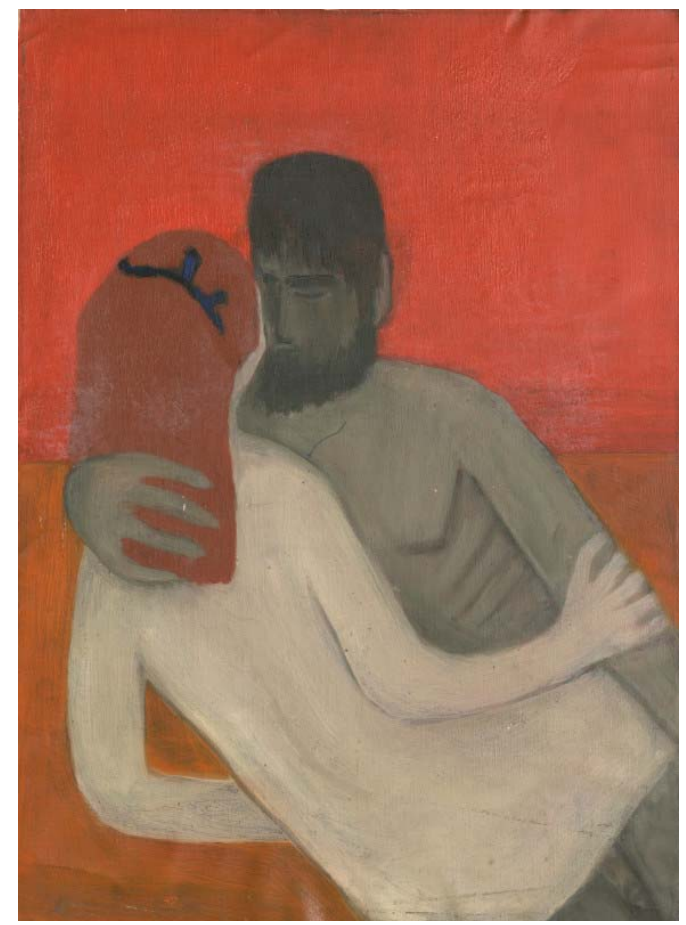

2. Kochankowie, lata 60. XX w. 


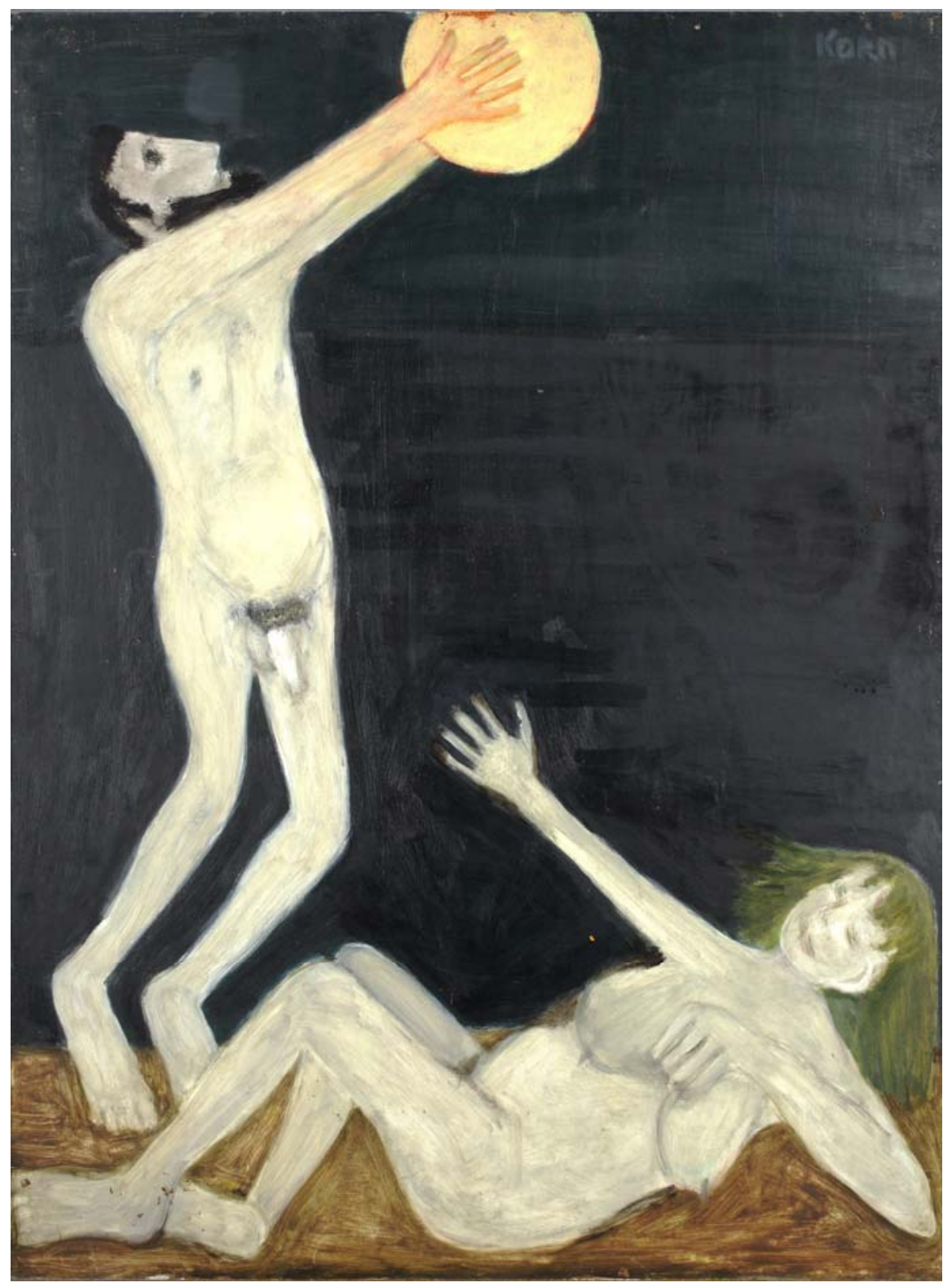

3. Kobieta i mężczyzna z piłka, ok. 1960-1964 


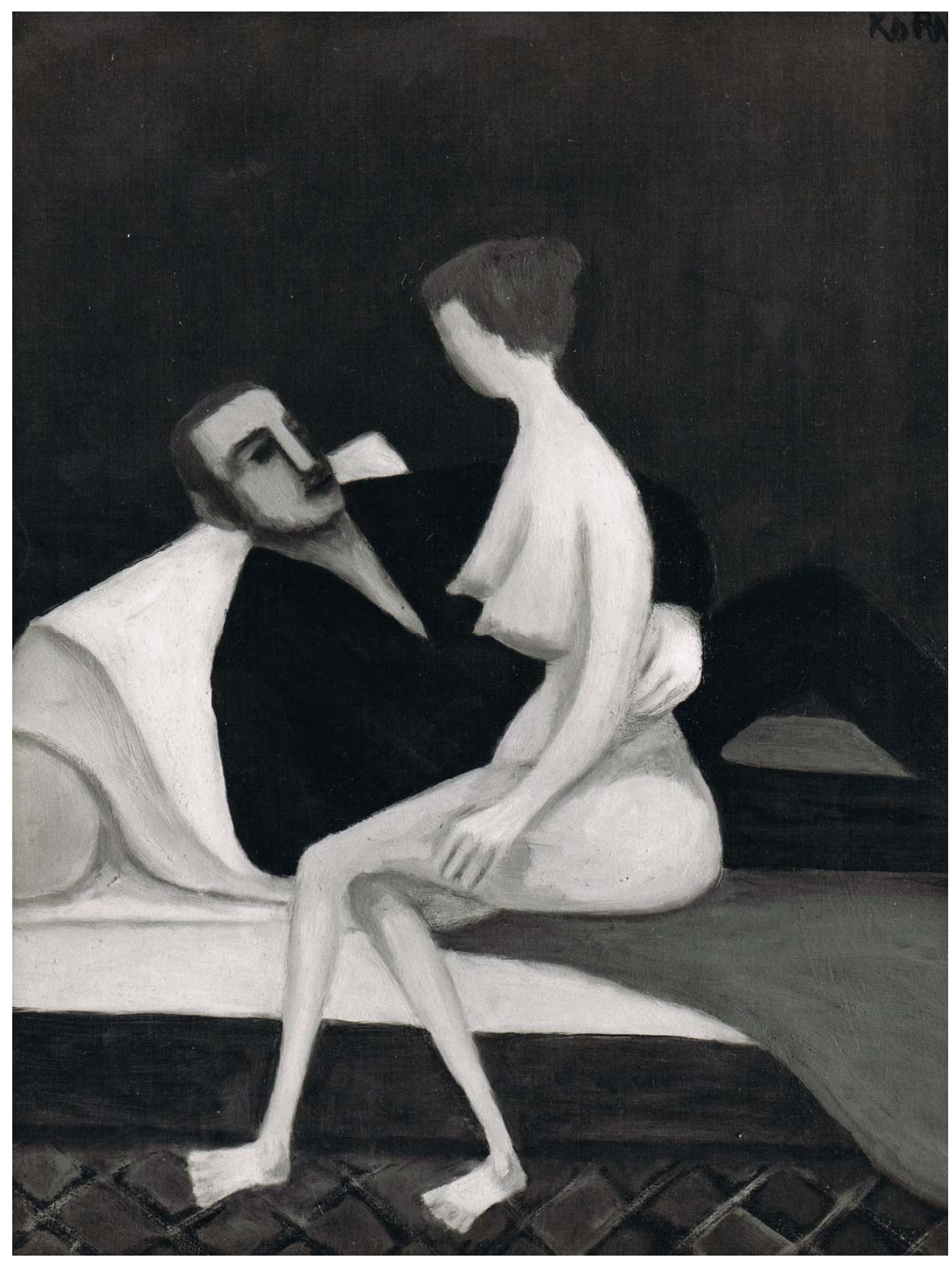

4. Mitość matżeńska, b.r. 


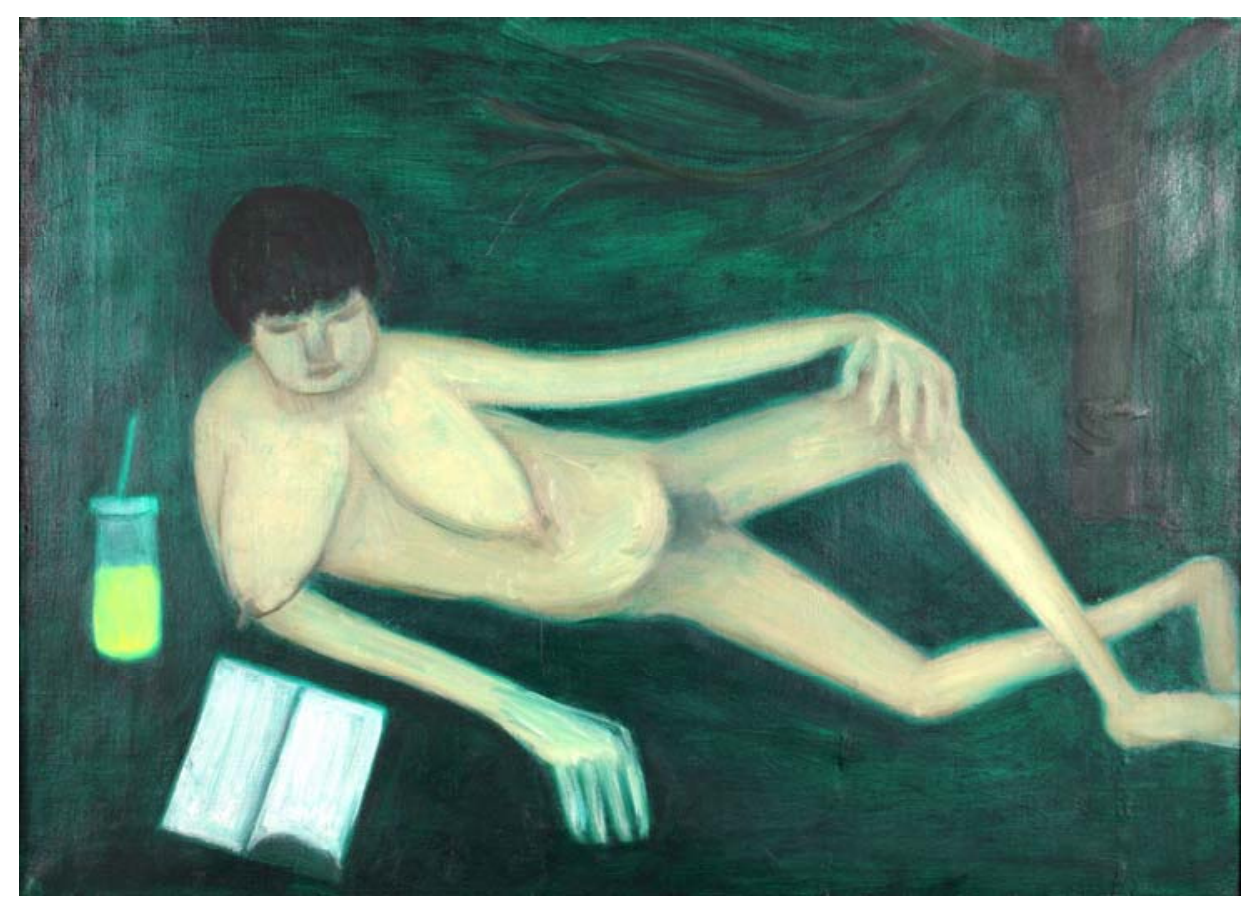

5. Kobieta leżaca na trawie, ok. 1960-1964

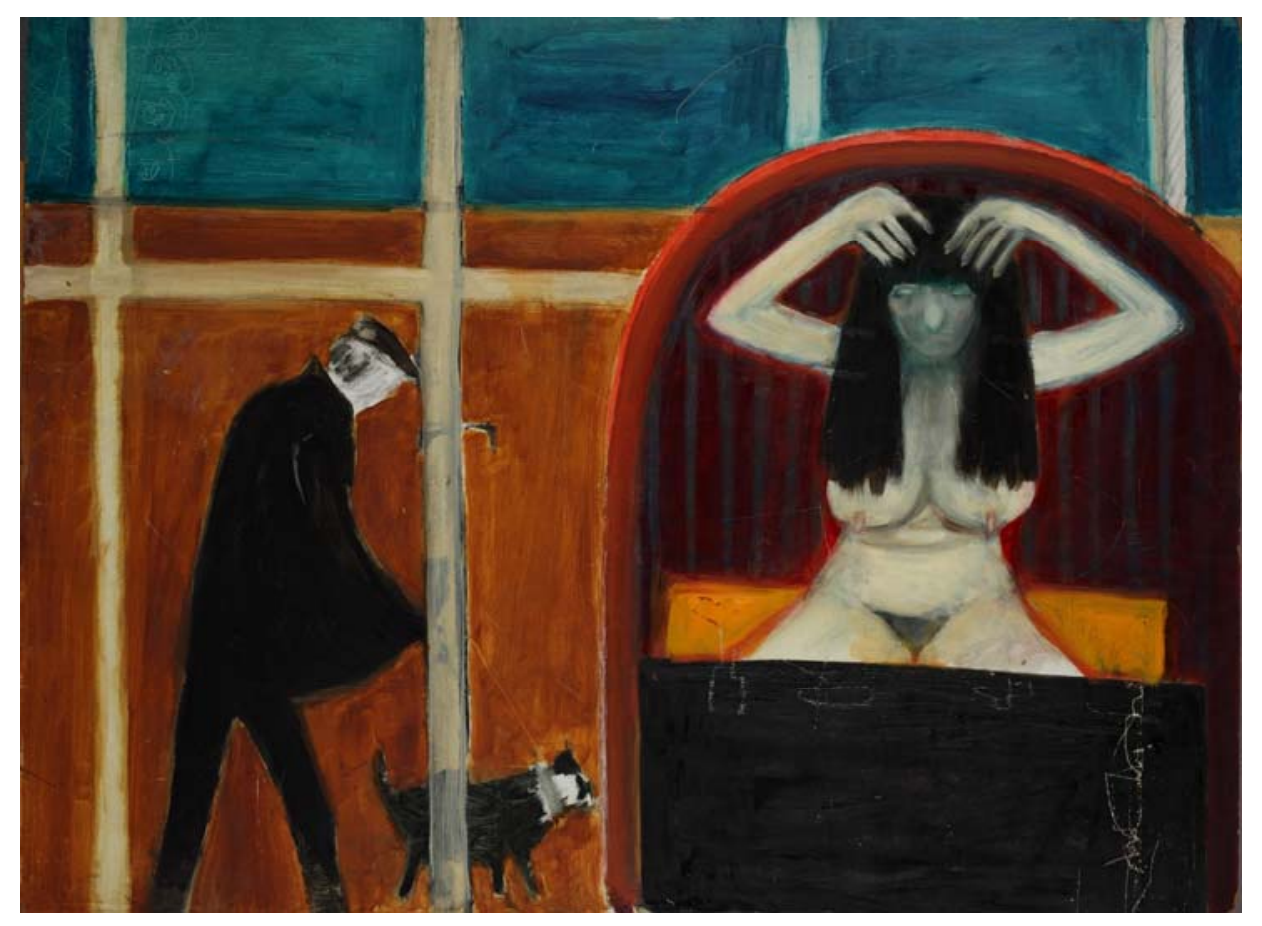

6. Kobieta myjąca włosy, ok. 1960-1964 


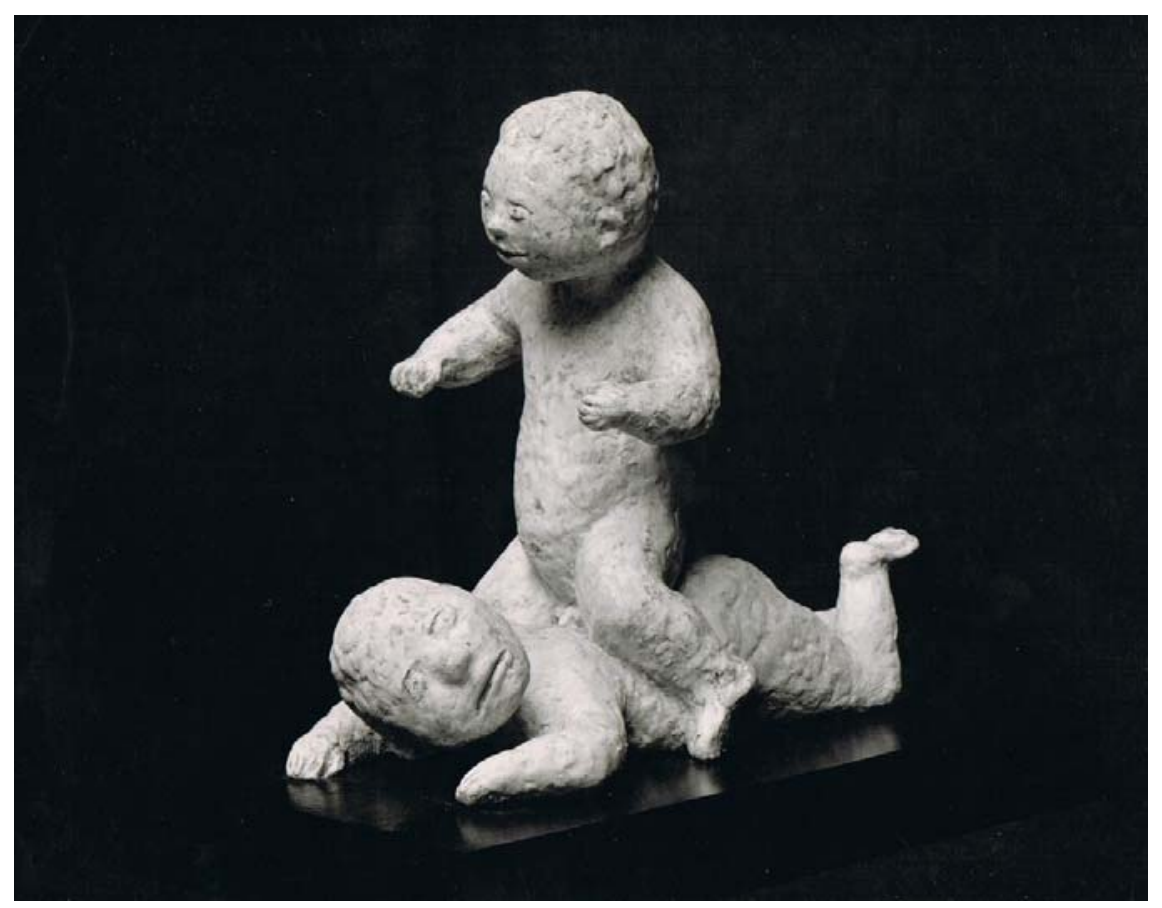

7. Fighting Kids, 1948

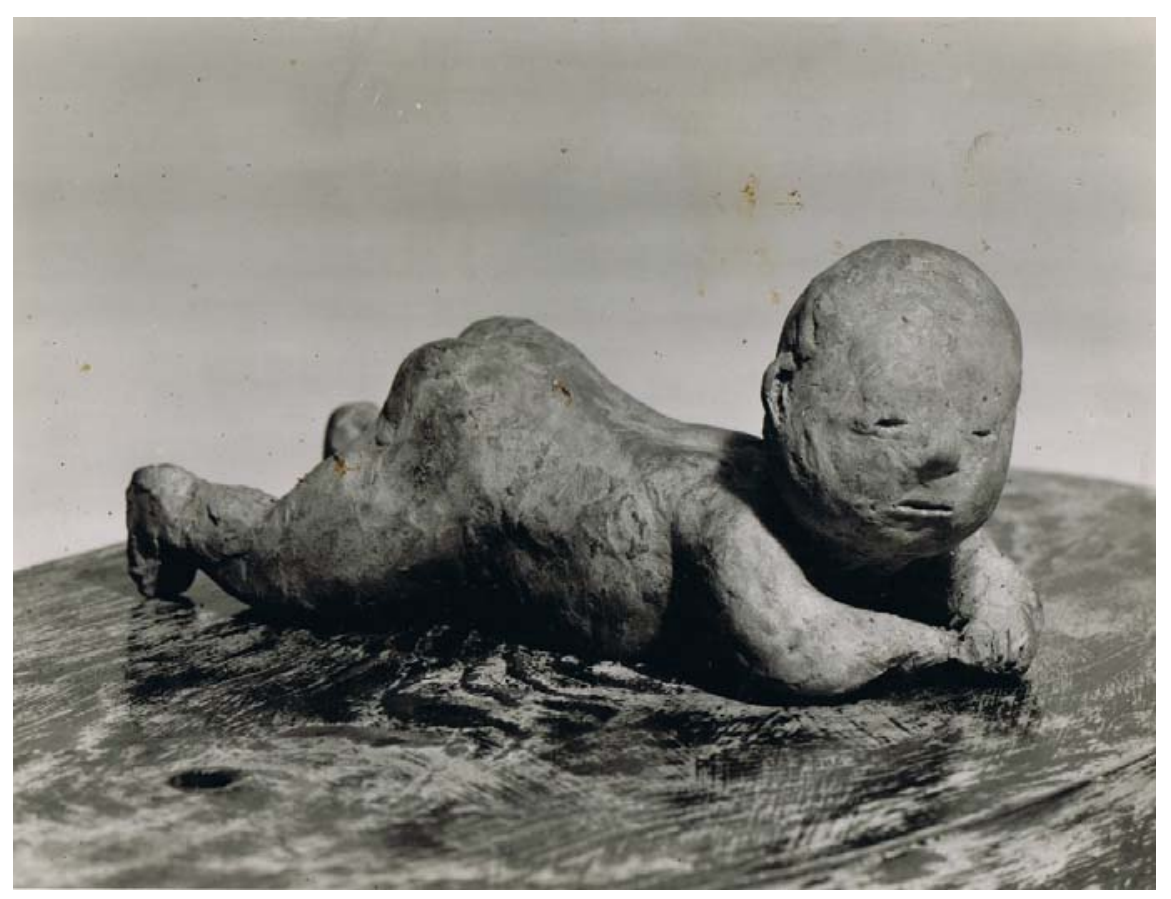

8. Portret dziecka, 1949 


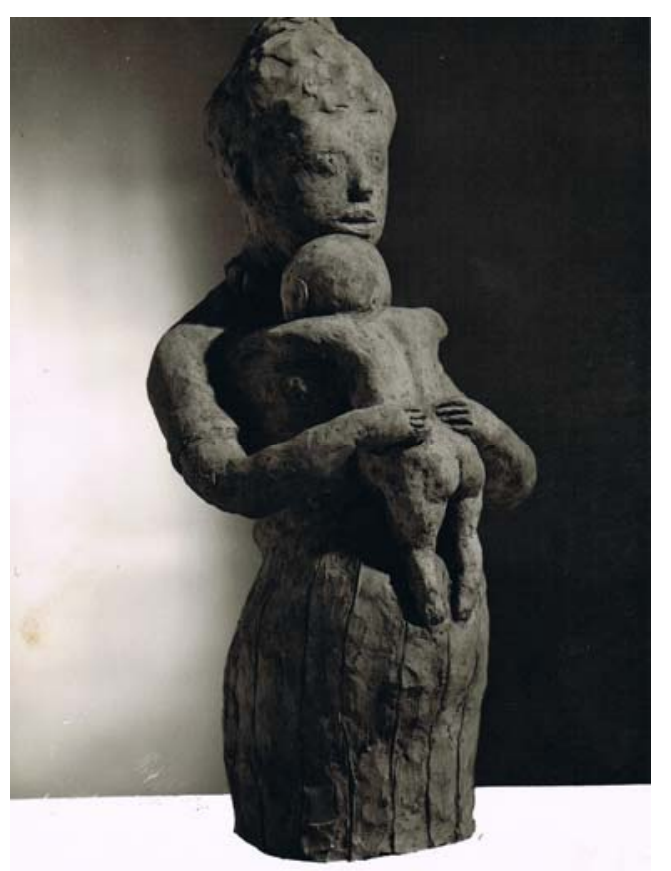

9. Matka i dziecko, b.r.

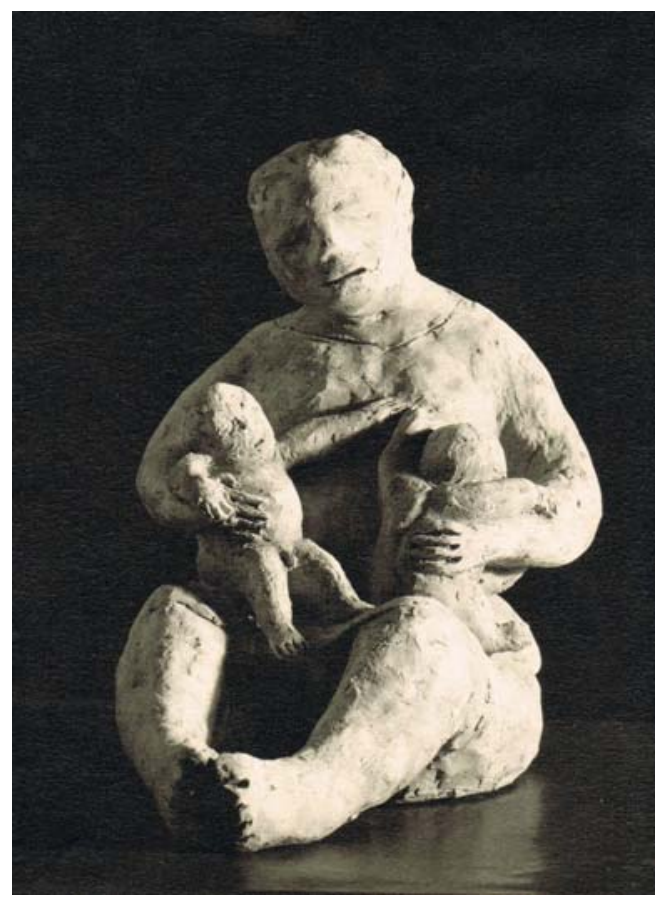

10. Macierzyństwo, 1950 